\title{
Psychomotor Retardation in Depression: A Systematic Review of Diagnostic, Pathophysiologic, and Therapeutic Implications
}

\author{
Djamila Bennabi, ${ }^{1,2}$ Pierre Vandel, ${ }^{1,2}$ Charalambos Papaxanthis, \\ Thierry Pozzo, ${ }^{3,4,5}$ and Emmanuel Haffen ${ }^{1,2,6}$ \\ ${ }^{1}$ Department of Clinical Psychiatry, University Hospital of Besançon, 25030 Besançon, France \\ ${ }^{2}$ EA 481 Neuroscience, IFR 133, University of Franche-Comte, 25030 Besançon, France \\ ${ }^{3}$ INSERM U1093 Cognition, Action, et Plasticité Sensorimotrice, University of Bourgogne, UFR STAPS, \\ 21078 Dijon, France \\ ${ }^{4}$ University of Bourgogne, UFR STAPS, 21078 Dijon, France \\ ${ }^{5}$ Institut Universitaire de France, University of Bourgogne, 21078 Dijon, France \\ ${ }^{6}$ Clinical Investigation Centre CIC-IT 808 INSERM, University Hospital of Besançon, 25030 Besançon, France
}

Correspondence should be addressed to Djamila Bennabi; djamila.bennabi@gmail.com

Received 14 May 2013; Revised 26 July 2013; Accepted 26 August 2013

Academic Editor: Michael Rapp

Copyright (C) 2013 Djamila Bennabi et al. This is an open access article distributed under the Creative Commons Attribution License, which permits unrestricted use, distribution, and reproduction in any medium, provided the original work is properly cited.

\begin{abstract}
Psychomotor retardation is a central feature of depression which includes motor and cognitive impairments. Effective management may be useful to improve the classification of depressive subtypes and treatment selection, as well as prediction of outcome in patients with depression. The aim of this paper was to review the current status of knowledge regarding psychomotor retardation in depression, in order to clarify its role in the diagnostic management of mood disorders. Retardation modifies all the actions of the individual, including motility, mental activity, and speech. Objective assessments can highlight the diagnostic importance of psychomotor retardation, especially in melancholic and bipolar depression. Psychomotor retardation is also related to depression severity and therapeutic change and could be considered a good criterion for the prediction of therapeutic effect. The neurobiological process underlying the inhibition of activity includes functional deficits in the prefrontal cortex and abnormalities in dopamine neurotransmission. Future investigations of psychomotor retardation should help improve the understanding of the pathophysiological mechanisms underlying mood disorders and contribute to improving their therapeutic management.
\end{abstract}

\section{Introduction}

Psychomotor retardation (PMR) has been recognized as one of the most fundamental features of major depressive disorder by the earliest psychiatric authors and is reflected in the use of various contemporary classification systems [1-3]. Descriptions of PMR have remained consistent in the literature; most portrayals of depressive symptomatology emphasised disturbances in speech, facial expression, fine motor behaviour, gross locomotor activity, or ideation [4-6]. Since the end of the 20th century, several authors have argued that the presence of clinical PMR allows determining clinically meaningful depressive subtypes (melancholic with and without psychotic features, bipolar and unipolar disorders) [7-9]. Other authors have proposed that motor retardation reflects a fundamental dimension of depression $[4,10]$. Moreover, motor disturbance in depression may indicate an underlying neuropathology and could be relevant in the context of therapeutic interventions [5]. Although psychomotor disturbances are included in most diagnostic systems and probably have prognostic and pathophysiological significance, explicit definitions of psychomotor phenomena remain elusive $[5,11]$. In order to specify the significance of psychomotor symptoms across the full spectrum of depressive disorders, experimental 
methods investigating motor and cognitive components of PMR have been developed. Objective psychomotor assessments may improve classification, longitudinal monitoring, treatment selection, and prediction of outcome in patients with depression.

The aim of this paper was to review the current status of knowledge about PMR in depression.

Our review focuses on empirical studies seeking to objectively quantify the manifestations of PMR. In addition, we have provided an overview of some of the conceptual and empirical backgrounds related to the pathophysiologic significance and the predictive value of PMR.

\section{Method}

Three electronic databases were searched to identify releva nt manuscripts: PubMed/Medline, Cochrane, and PsycInfo. Our initial search strategy included one main term, namely, "depressive disorder," combined with the following: «psychomotor retardation》, «motor activity», «psychomotor disorders $\gg$, and «perceptual motor processes $\gg$. The reference lists of the selected manuscripts were scrutinised for additional studies.

Studies were limited to human studies reported in English and were eligible for inclusion if they addressed both depression and retardation symptoms. Articles were included if they contained primary data derived from clinical trials or longitudinal or cross-sectional studies. Excluded studies were those addressing depression due to specific disease processes (e.g., Parkinson's disease or dementia). We initially applied the above eligibility criteria to the citations and abstracts generated by the search. Based on this information, we excluded publications not meeting the inclusion criteria. When an article met the inclusion criteria, or when there was not sufficient information to definitely exclude it, we retrieved the full text. We then reviewed these potentially relevant articles to determine whether the inclusion criteria were in fact met. Of the 144 papers where full-text articles were reviewed, we excluded a total of 28 articles; 24 studies did not meet eligibility criteria, and 4 presented duplicate data. Thus, we obtained data from 116 papers that met our eligibility criteria.

The reviewed studies are listed in Tables 1, 2 and 3, according to sample, design, measure, and results. Diagnoses were more often based on DSM or Research Diagnostic Criteria. The main observations are that (i) most samples sizes are relatively large, (ii) the majority of the studies include a control group, (iii) the assessment methods and outcomes measures differed substantially across studies, and (iv) there were few discrepancies in the findings, mainly due to the homogeneity of the methodology.

\section{Results}

3.1. Assessments of PMR. Longitudinal investigations of motor behaviour are complicated by the effects of confounds such as motivational factors, psychotropic medication, or time of assessment [12]. Motivational factors including interest, pleasure, and reactivity to pleasurable stimuli contribute to the initiation and progression of motor activity and may interfere with the expression of retardation $[13,14]$. Circadian rhythms are another confounding factor, with retardation being more pronounced during the morning than in the evening. Psychoactive medication may have disruptive effects on psychomotor functioning, causing sedation or impairment in psychomotor and cognitive function [15].

3.1.1. Clinical Assessments. Clinical rating scales of depression typically include only one item for psychomotor disturbance, and cognitive or motor aspects of agitation and retardation are intermixed [16-18]. The Hamilton Depression Rating Scale (HDRS), for example, contains only two of the 17 items assessing psychomotor symptoms. Retardation also appears indirectly in several different items concerning fatigue, loss of energy, or lack of concentration. Three scales have been specifically designed to assess PMR in depression, each addressing different objectives: the Salpetrière Retardation Rating Scale (SRRS), the CORE index of melancholia, and the Motor Agitation and Retardation Scale (MARS) [19-21].

(a) The Salpetrière Retardation Rating Scale (SRRS). The SRRS, developed by Widlöcher, focuses on motor and cognitive aspects of retardation. This author considered PMR as a unique global process including motor and psychic observational disturbances. The SRRS has been used in a number of studies to measure severity of psychomotor retardation or its capacity to predict response to antidepressant medication. This scale contains fifteen items, each scored from 0 (normal) to 4 (severe) with a total score range of 0 to 60 . The first 6 items gauge different manifestations of motor retardation such as slowness of gait, limb movement, or speech. The next two items are designed to objectively assess cognitive function, whereas the last 5 are related to subjective appreciation of cognitive activities. One additional item proposed a global evaluation of psychomotor retardation. Factor analysis suggested a three-factor solution: the first factor, including all items, accounted for $60 \%$ of the cumulative variance; the second factor was composed of SRRS items 1 to 5 , which are motor retardation items; the third factor was composed of items which grade subjective experience of retardation and is influenced by anxiety. Correlations between SRRS and HDRS $(r=0.58)$ or MADRS $(r=0.68)$ have indicated good convergent validity [19]. Otherwise, the SRRS has been found to have strong correlations with motor and cognitive measures of retardation such as speech pause time [22, 23], level of activity [10, 24-26], or reaction time. Bonin-Guillaume et al. designed the Retardation Rating Scale (RRS) to evaluate the global aspect of PMR in the geriatric population [27]. The RRS includes items related to motor and cognitive retardation and differs from the SRRS with one additional item rating motility and one less rating speech. This scale has proven to have good psychometric properties in subjects who are over 80 . 
TABLE 1: Studies exploring experimental assessments of psychomotor retardation.

\begin{tabular}{|c|c|c|c|c|}
\hline Authors & Sample (criteria) & Treatments & Measure & Variables \\
\hline Szabadi et al. 1976 [28] & $\begin{array}{c}\text { Depressed }=4(\mathrm{NS}) \\
\quad \text { Controls }=4\end{array}$ & Amitriptyline & $\begin{array}{l}\text { Automatic speech } \\
\text { HDRS }\end{array}$ & $\begin{array}{l}\text { Speech pause time } \\
\text { Phonation time }\end{array}$ \\
\hline Greden et al. 1981 [29] & $\begin{array}{c}\mathrm{MDD}=36(\mathrm{RDC}) \\
24 \mathrm{UP} / 12 \mathrm{BP} \\
\text { Controls = } 19\end{array}$ & NS & $\begin{array}{l}\text { Automatic speech } \\
\text { HDRS }\end{array}$ & $\begin{array}{l}\text { Speech pause time } \\
\text { Phonation time }\end{array}$ \\
\hline Hardy et al. 1984 [22] & $\mathrm{MDD}=16(\mathrm{DSM} \mathrm{III})$ & $\begin{array}{l}\text { Clomipramine } \\
\text { Mianserin ECT }\end{array}$ & $\begin{array}{l}\text { Automatic speech } \\
\text { HDRS } \\
\text { SRRS }\end{array}$ & $\begin{array}{l}\text { Speech pause time } \\
\text { Phonation time }\end{array}$ \\
\hline Hoffmann et al. 1985 [23] & $\begin{array}{c}\mathrm{MDD}=22(\mathrm{RDC}) \\
12 \mathrm{UP} / 10 \mathrm{BP} \\
\text { Controls = } 15\end{array}$ & Drug-free & $\begin{array}{l}\text { Automatic speech } \\
\text { SRRS } \\
\text { DST/REM }\end{array}$ & $\begin{array}{l}\text { Speech pause time } \\
\text { Phonation time } \\
\text { Cortisol levels } \\
\text { REM latency }\end{array}$ \\
\hline Nilsonne 1987 [30] & $\begin{array}{c}\mathrm{MEL}=8(\mathrm{RDC}) \\
\text { non-MEL }=8\end{array}$ & $\begin{array}{l}\text { Antidepressant } \\
\text { Neuroleptics } \\
\text { Lithium }\end{array}$ & $\begin{array}{l}\text { Automatic speech } \\
\text { CPRS }\end{array}$ & $\begin{array}{l}\text { Speech pause time } \\
\text { Phonation time } \\
\text { FO }\end{array}$ \\
\hline Nilsonne 1988 [31] & $\begin{array}{l}\mathrm{MEL}=21(\mathrm{DSM} \text { III }) \\
\text { non-MEL = } 7\end{array}$ & $\begin{array}{l}\text { Antidepressant } \\
\text { Neuroleptics }\end{array}$ & $\begin{array}{l}\text { Automatic speech } \\
\text { Free speech }\end{array}$ & $\begin{array}{l}\text { Speech pause time } \\
\text { Phonation time } \\
\text { FO } \\
5 \mathrm{P}\end{array}$ \\
\hline Kuny St. and Stassen 1993 [32] & $\begin{array}{l}\mathrm{MDD}=30(\mathrm{ICD}) \\
\text { Controls }=30\end{array}$ & Antidepressant & $\begin{array}{l}\text { Automatic speech } \\
\text { HDRS }\end{array}$ & $\begin{array}{l}\text { Speak flow } \\
\text { Prosody }\end{array}$ \\
\hline Flint et al. 1993 [33] & $\begin{array}{c}\text { MDD }=30(\text { DSM III-R }) \\
+ \text { aged }>60 \\
\text { Controls }=30 \\
\text { Parkinsonian }=30\end{array}$ & Antidepressant & $\begin{array}{l}\text { Automatic speech } \\
\text { HDRS }\end{array}$ & $\begin{array}{l}\text { F2 } \\
\text { Spirantization } \\
\text { Voice onset time }\end{array}$ \\
\hline Alpert et al. 2001 [34] & $\begin{array}{c}\mathrm{MDD}=12(\mathrm{DSM} \text { III-R }) \\
\quad+\text { aged over } 60 \\
+ \text { HDRS } \geq 20\end{array}$ & $\begin{array}{l}\text { Sertraline } \\
\text { Nortriptyline }\end{array}$ & $\begin{array}{l}\text { Automatic speech } \\
\text { Free speech } \\
\text { HDRS }\end{array}$ & $\begin{array}{l}\text { Fluency and prosody at day } 0 \\
\text { and week } 12\end{array}$ \\
\hline Cannizzaro et al. 2004 [35] & $\begin{array}{c}\text { Depressed }=7(\mathrm{NS}) \\
\quad+\mathrm{HDRS} \geq 17\end{array}$ & NS & $\begin{array}{l}\text { Free speech } \\
\text { HDRS }\end{array}$ & $\begin{array}{l}\text { Speech pause time } \\
\text { Phonation time } \\
\text { FO }\end{array}$ \\
\hline Hergueta et al. 1996 [36] & $\begin{array}{l}\mathrm{MDD}=40(\mathrm{DSM} \text { IV }) \\
\text { Controls }=40\end{array}$ & $\begin{array}{l}\text { Tricyclics } \\
\text { IMAO } \\
\text { SRRI }\end{array}$ & Gait analysis & $\begin{array}{l}\text { Spatial and temporal } \\
\text { parameters of gait }\end{array}$ \\
\hline Lemke et al. 2000 [37] & $\begin{array}{l}\mathrm{MDD}=12(\mathrm{DSM} \text { IV }) \\
\text { Controls }=16\end{array}$ & $\begin{array}{l}\text { Amitriptyline } \\
\text { Paroxetine } \\
\text { Doxepin }\end{array}$ & Gait analysis & $\begin{array}{l}\text { Stride length } \\
\text { Gait velocity } \\
\text { Double limb support }\end{array}$ \\
\hline Hausdorff et al. 2004 [38] & $\begin{array}{c}\mathrm{MDD}=32(\mathrm{DSM} \text { IV }) \\
\text { Controls }=18\end{array}$ & NS & Gait analysis & $\begin{array}{l}\text { Stride time variability } \\
\text { Swing time variability }\end{array}$ \\
\hline Lecrubier 2006 [39] & $\begin{array}{c}\text { Depressed }=26(\mathrm{NS}) \\
\text { Controls }=18\end{array}$ & Antidepressant & $\begin{array}{l}\text { Gait Analysis before } \\
\text { and after treatment }\end{array}$ & $\begin{array}{l}\text { Speed of propulsion of heel } \\
\text { Stride length }\end{array}$ \\
\hline Royant-Parola et al. 1986 [26] & $\mathrm{UP}=12(\mathrm{DSM} \mathrm{III})$ & $\begin{array}{l}\text { Tricyclics } \\
\text { Mianserin } \\
\text { Benzodiazepine }\end{array}$ & Actimetry SRRS & $\begin{array}{l}\text { Level of activity } \\
\text { Index of immobility }\end{array}$ \\
\hline Dantchev et al. 1992 [25] & $\begin{array}{c}\text { MDD = } 13 \\
(\mathrm{DSM} \text { III-R) }\end{array}$ & Trimipramine & $\begin{array}{l}\text { Actimetry SRRS } \\
\text { MADRS }\end{array}$ & $\begin{array}{l}\text { Level of activity } \\
\text { Index of immobility }\end{array}$ \\
\hline Raoux 1994 [24] & $\begin{array}{c}\text { MDD }=26 \\
(\mathrm{DSM} \text { III-R) } \\
+ \text { MADRS }>25\end{array}$ & Tricyclics & Actimetry SRRS & $\begin{array}{l}\text { Level of activity } \\
\text { Index of immobility }\end{array}$ \\
\hline Volkers et al. 2003 [40] & $\begin{array}{c}\mathrm{MDD}=67 \mathrm{UP}(\mathrm{DSM} \text { IV }) \\
\text { Controls }=67\end{array}$ & Drug-free & Actimetry SADS & $\begin{array}{l}\text { Level of activity } \\
\text { Fragmentation index }\end{array}$ \\
\hline Iverson 2004 [41] & $\begin{array}{c}\mathrm{MDD}=48(\mathrm{DSM} \text { IV }) \\
\text { Controls }=25\end{array}$ & NS & Actimetry & Level of activity \\
\hline Lemke et al. 1997 [13] & $\mathrm{MEL}=16(\mathrm{DSM}$ IV $)$ & $\begin{array}{l}\text { Antidepressant } \\
\text { Benzodiazepine }\end{array}$ & Actimetry MAACL & Level of activity \\
\hline Lemke and Schleidt 1999 [42] & $\begin{array}{c}\mathrm{MDD}=12(\mathrm{DSM} \text { IV }) \\
\text { Controls }=30\end{array}$ & Amitriptyline & $\begin{array}{l}\text { Video analysis of limb } \\
\text { movements }\end{array}$ & Unit of action \\
\hline
\end{tabular}


TABle 1: Continued.

\begin{tabular}{|c|c|c|c|c|}
\hline Authors & Sample (criteria) & Treatments & Measure & Variables \\
\hline Aybek et al. 2008 [43] & $\begin{array}{l}\mathrm{MDD}=4(\mathrm{DSM} \mathrm{IV}) \\
\text { Controls }=7\end{array}$ & NS & $\begin{array}{l}\text { Movements of the } \\
\text { limbs }\end{array}$ & $\begin{array}{l}\text { Velocity and amplitude of the } \\
\text { movements }\end{array}$ \\
\hline van Hoof et al. 1993 [44] & $\begin{array}{c}\text { MDD = 20 } \\
(\text { DSM III-R) } \\
\text { Controls }=20\end{array}$ & $\begin{array}{l}\text { Clomipramine } \\
\text { Amitriptyline } \\
\text { Neuroleptics }\end{array}$ & $\begin{array}{l}\text { Drawing tasks } \\
\text { SRRS }\end{array}$ & $\begin{array}{l}\text { Movement time } \\
\text { Reaction time } \\
\text { Reinspection time }\end{array}$ \\
\hline Sabbe et al. 1996 [45] & $\begin{array}{c}\text { MDD = 22 } \\
\text { (DSM III-R) } \\
\text { Controls = 22 }\end{array}$ & $\begin{array}{l}\text { Fluoxetine } \\
\text { Benzodiazepine } \\
\text { Neuroleptic }\end{array}$ & $\begin{array}{l}\text { Drawing tasks } \\
\text { SRRS }\end{array}$ & $\begin{array}{l}\text { Movement time } \\
\text { Reaction time }\end{array}$ \\
\hline Sabbe et al. 1999 [46] & $\begin{array}{c}\text { MDD = } 30 \\
(\mathrm{DSM} \text { III-R) } \\
\text { Controls = } 30\end{array}$ & $\begin{array}{l}\text { Fluoxetine } \\
\text { Benzodiazepine } \\
\text { Neuroleptic }\end{array}$ & Drawing tasks & $\begin{array}{l}\text { Movement time } \\
\text { Velocity }\end{array}$ \\
\hline Pier et al. 2004 [47] & $\begin{array}{c}\text { MEL }=20(\text { DSM IV }) \\
\text { non-MEL }=18 \\
\text { Controls }=38\end{array}$ & Hypnotic & $\begin{array}{l}\text { Drawing tasks } \\
\text { SRRS }\end{array}$ & $\begin{array}{l}\text { Movement time } \\
\text { Reaction time } \\
\text { Reinspection time }\end{array}$ \\
\hline Pier et al. 2004b [48] & $\begin{array}{c}\mathrm{MDD}=12(\mathrm{DSM} \mathrm{IV}) \\
+ \text { age }>65 \\
\text { Controls }=12\end{array}$ & $\begin{array}{l}\text { Antidepressant } \\
\text { Neuroleptic } \\
\text { Mood stabilizer }\end{array}$ & $\begin{array}{l}\text { Drawing tasks } \\
\text { SRRS }\end{array}$ & $\begin{array}{l}\text { Movement time } \\
\text { Reaction time } \\
\text { Reinspection time }\end{array}$ \\
\hline Mergl et al. 2004 [49] & $\mathrm{MDD}=37(\mathrm{ICD} 10)$ & $\begin{array}{l}\text { Antidepressant } \\
\text { Mood stabilizer }\end{array}$ & $\begin{array}{l}\text { Drawing tasks } \\
\text { Writing tasks }\end{array}$ & Kinematic parameters \\
\hline Hoffstaedter et al. 2012 [50] & $\begin{array}{l}\mathrm{MDD}=20(\mathrm{ICD} 10) \\
\text { Controls }=20\end{array}$ & $\begin{array}{l}\text { Antidepressant } \\
\text { Mood stabilizer } \\
\text { Antipsychotic }\end{array}$ & $\begin{array}{l}\text { Motor tasks } \\
\text { Combined motor and } \\
\text { cognitive measures }\end{array}$ & $\begin{array}{l}\text { Reaction time } \\
\text { Movement time } \\
\text { Error rates }\end{array}$ \\
\hline Schwartz et al. 1976 [51] & $\begin{array}{l}\text { Depressed }=12(\mathrm{NS}) \\
\quad \text { Controls }=12\end{array}$ & None & $\begin{array}{l}\text { Facial EMG during } \\
\text { the generation of } \\
\text { affective imagery }\end{array}$ & EMG patterns \\
\hline Sweeney et al. 1998 [52] & $\begin{array}{l}\text { MDD = 29 } \\
(\mathrm{DSM} \text { III-R) }\end{array}$ & None & Eye tracking & Latency of eye movements \\
\hline Mahlberg et al. 2001 [53] & $\begin{array}{c}\text { Depressed }=32(\mathrm{NS}) \\
\text { Controls }=42\end{array}$ & NS & Eye tracking & $\begin{array}{l}\text { Pro-saccades } \\
\text { Predictive saccades }\end{array}$ \\
\hline Winograd-Gurvich et al. 2006 [54] & $\begin{array}{c}\mathrm{MEL}=10(\mathrm{DSM} \text { IV }) \\
\text { non-MEL = } 9\end{array}$ & NS & Eye tracking & Latency of eye movements \\
\hline Blackburn 1975 [55] & $\begin{array}{c}\text { Depressive UP and BP: } \\
106(\mathrm{NS})\end{array}$ & NS & $\begin{array}{l}\text { Nufferno speed test } \\
\text { Gibson spiral maze }\end{array}$ & Reaction time \\
\hline Cornell et al. 1984 [56] & $\begin{array}{c}\text { MEL }=14(\text { DSM III }) \\
\text { non-MEL }=14 \\
(\text { DSM III) } \\
\text { Controls }=14\end{array}$ & None & Reaction choice test & $\begin{array}{l}\text { "Motor" RT } \\
\text { "Cognitive" RT }\end{array}$ \\
\hline Smith et al. 1994 [57] & $\begin{array}{l}\text { MDD = } 36(\mathrm{DSM} \text { III }) \\
\text { Controls }=36\end{array}$ & Antidepressant & $\begin{array}{l}\text { Signal detection time } \\
\text { SRRS } \\
\text { MADRS }\end{array}$ & $\begin{array}{l}\text { False alarms } \\
\text { Omissions }\end{array}$ \\
\hline Moffot et al. 1994 [12] & $\begin{array}{c}\text { MEL = 20 } \\
(\mathrm{DSM} \text { III-R) } \\
\text { Controls = } 20\end{array}$ & $\begin{array}{l}\text { Antidepressant } \\
\text { Mood stabilizer }\end{array}$ & $\begin{array}{l}\text { Tests at } 8 \mathrm{PM} \text { and } \mathrm{AM} \\
\text { DSST } \\
\text { CANTAB } \\
\text { Strength }\end{array}$ & $\begin{array}{l}\text { Reaction time } \\
\text { Movement time }\end{array}$ \\
\hline Smith et al. 1995 [58] & $\begin{array}{c}\text { MEL = } 32 \\
(\text { DSM III-R) } \\
+ \text { MADRS }>22 \\
\text { Controls }=32\end{array}$ & $\begin{array}{l}\text { Antidepressant } \\
\text { Benzodiazepine }\end{array}$ & $\begin{array}{l}\text { Modified version of } \\
\text { the Posner test } \\
\text { SRRS }\end{array}$ & Reaction time \\
\hline Brebion et al. 1995 [59] & $\begin{array}{c}\text { MDD = 29 } \\
(\text { DSM III-R) } \\
\text { Controls = } 26\end{array}$ & $\begin{array}{l}\text { Antidepressant } \\
\text { Anxiolytic }\end{array}$ & $\begin{array}{l}\text { Reaction time task } \\
\text { SRRS } \\
\text { MADRS }\end{array}$ & Reaction time \\
\hline Brébion et al. 1997 [60] & $\begin{array}{c}\text { MDD = 26 } \\
(\text { DSM III-R) } \\
+ \text { MADRS }>20 \\
\text { Controls }=26\end{array}$ & $\begin{array}{l}\text { Antidepressant } \\
\text { Benzodiazepine }\end{array}$ & $\begin{array}{l}\text { Recognition memory } \\
\text { task } \\
\text { SRRS }\end{array}$ & $\begin{array}{l}\text { Index of response bias } \\
\text { Index of discrimination }\end{array}$ \\
\hline Lemelin et al. 1996 [61] & $\begin{array}{c}\mathrm{MDD}=30(\mathrm{DSM} \text { IV }) \\
\text { Controls }=30\end{array}$ & None & $\begin{array}{l}\text { Stroop test } \\
\text { SRRS }\end{array}$ & $\begin{array}{l}\text { Reaction time } \\
\text { Interference score }\end{array}$ \\
\hline
\end{tabular}


TABLE 1: Continued.

\begin{tabular}{|c|c|c|c|c|}
\hline Authors & Sample (criteria) & Treatments & Measure & Variables \\
\hline Lemelin and Baruch 1998 [62] & $\begin{array}{c}\mathrm{MDD}=30(\mathrm{DSM} \text { IV }) \\
\text { Controls }=34\end{array}$ & None & $\begin{array}{l}\text { Stroop test } \\
\text { SRRS }\end{array}$ & $\begin{array}{l}\text { Reaction time } \\
\text { Interference score }\end{array}$ \\
\hline Bonin-Guillaume et al. 2008 [63] & $\begin{array}{c}\mathrm{MDD}=16(\mathrm{DSM} \text { IV }) \\
+ \text { GDS }>11 \\
+ \text { age }>65 \\
\text { Controls }=16\end{array}$ & NS & $\begin{array}{l}\text { Reaction time task } \\
\text { SRRS }\end{array}$ & Reaction time \\
\hline Chen et al. 2013 [64] & $\begin{array}{c}\mathrm{MDD}=33(\mathrm{DSM} \mathrm{IV}) \\
\text { Controls }=30\end{array}$ & Antidepressant & $\begin{array}{l}\text { Ego-rotation and } \\
\text { object-rotation tasks }\end{array}$ & $\begin{array}{l}\text { Reaction time } \\
\text { Error rates }\end{array}$ \\
\hline Caligiuri and Ellwanger 2000 [65] & $\begin{array}{c}\mathrm{MDD}=36(\mathrm{DSM} \text { IV }) \\
\text { Controls }=22\end{array}$ & $\begin{array}{l}\text { Antidepressant } \\
\text { Neuroleptic } \\
\text { Benzodiazepine }\end{array}$ & Wrist movements & $\begin{array}{l}\text { Reaction Time } \\
\text { Movement time }\end{array}$ \\
\hline van Hoof et al. 1998 [66] & $\begin{array}{c}\text { MDD }=20 \\
(\text { DSM III-R) } \\
\text { Schizophrenic }=20\end{array}$ & $\begin{array}{l}\text { Antidepressant } \\
\text { Neuroleptic } \\
\text { Benzodiazepine }\end{array}$ & $\begin{array}{l}\text { DSST } \\
\text { SRRS }\end{array}$ & $\begin{array}{l}\text { Observation time } \\
\text { Writing time }\end{array}$ \\
\hline Rogers et al. 1987 [67] & $\begin{array}{c}\mathrm{MDD}=30(\mathrm{RDC}) \\
\text { Parkinson }=20 \\
\text { Controls } 30\end{array}$ & $\begin{array}{l}\text { Antidepressant } \\
\text { Benzodiazepine } \\
\text { Mood stabilizer } \\
\text { Neuroleptic }\end{array}$ & $\begin{array}{l}\text { DSST } \\
\text { WBS }\end{array}$ & $\begin{array}{l}\text { Reaction time } \\
\text { Movement time }\end{array}$ \\
\hline Rogers et al. 2000 [68] & $\begin{array}{c}\mathrm{MEL}=12(\mathrm{DSM} \mathrm{IV}) \\
\text { non-MEL }=12 \\
\text { Controls }=24\end{array}$ & $\begin{array}{l}\text { Antidepressant } \\
\text { Benzodiazepine } \\
\text { Mood stabilizer }\end{array}$ & $\begin{array}{l}\text { Reaction time task } \\
\text { CORE }\end{array}$ & Reaction time \\
\hline El Massioui et al. 1996 [69] & $\begin{array}{c}\text { MDD }=8 \\
(\text { DSM III-R) } \\
+ \text { score SRRS }>27 \\
\text { Controls }=9\end{array}$ & None & $\begin{array}{l}\text { Event-related } \\
\text { potential }\end{array}$ & $\begin{array}{l}\text { Reaction time } \\
\text { Amplitude and latency of P3, } \\
\text { N1, and N2 }\end{array}$ \\
\hline Bange and Bathien 1998 [70] & $\begin{array}{c}\mathrm{MDD}=23(\mathrm{DSM} \text { III-R }) \\
\text { Controls }=20\end{array}$ & $\begin{array}{l}\text { Antidepressant } \\
\text { Mood stabilizer }\end{array}$ & $\begin{array}{l}\text { Event-related } \\
\text { potential }\end{array}$ & $\begin{array}{l}\text { Reaction tme } \\
\text { Amplitude and latency of P3, } \\
\text { N1, and N2 }\end{array}$ \\
\hline Schrijvers et al. 2009 [71] & $\begin{array}{c}\mathrm{MDD}=26(\mathrm{DSM} \text { IV }) \\
\text { Controls }=26\end{array}$ & NS & $\begin{array}{l}\text { EEG } \\
\text { Drawing tasks }\end{array}$ & $\begin{array}{l}\text { Error Negativity }(\mathrm{Ne}) \\
\text { Reaction time }\end{array}$ \\
\hline
\end{tabular}

BP: bipolar; UP: unipolar; CPRS: Comprehensive Psychopathological Rating Scale; CANTAB: computerised psychometric testing battery; DSM: Diagnostic and Statistic Manual of Mental Disorders; DST: suppression dexamethasone Test; DSST: digit symbol substitution test; EEG: electroencephalography; EMG: Electromyography; F0: Fundamental Frequency; HDRS: Hamilton Depression Rating Scale; ICD: International Statistical Classification of Diseases and Related Health Problems; MAACL: multiple affective adjective checklist; IMAO: monoamine oxydase inhibitor; GDS: Geriatric Depression Scale; MADRS: Montgomery Asberg Depression Rating Scale; MDD: major depressive disorder; MEL: melancholic; non-MEL: nonMelancholic; MT: movement time; NS: not specified; PMR: psychomotor retardation; PT: phonation time; RDC: Research Diagnosis Criteria; REM: rapid eye Movements; RT: reaction time; SADS: Schedule for Affective Disorders and Schizophrenia; SPT: speech pause time; SRRI: selective serotonin reuptake inhibitor; SRRS: Salpetrière Retardation Rating Scale; WBS: Webster Rating Scale.

(b) The CORE Index. This measure was designed to sybtype depressed patients into melancholic and nonmelancholic groups and supports the hypothesis that retardation and agitation symptoms distinguish endogenous psychotic depression from neurotic and reactive depression. [7, 21]. As instrument rates are used to assess observed behavioural nuances, clinical experience with depressed patients (especially the severely depressed) is required. The CORE index is composed of 18 items, scored on a 4 -point scale. A score of 0 indicates that the sign is absent or trivial, while scores of 1 to 3 indicate definite presence with increasing severity. The total score range of 0 to 54 and a cut-off score of 21 are used to classify melancholic depression. Factor analysis showed three interpretable domains: (1) retardation items (52\% of variance), (2) agitation items (15\% of variance), and (3) noninteractiveness (5\% of variance). The factor «noninteractiveness $\gg$ refers to items, «length of verbal responses» and «poverty of associations $\gg$. Further CORE scores are associated with nonsuppression of cortisol following overnight dexamethasone [85] electronic measures of neuropsychological slowing [119]. This scale has a good structural validity, good internal consistency, and convergent validity. The CORE index is used to quantify the degree of psychomotor impairment or to constitute subgroups of patients suffering from melancholic depression.

(c) The Motor Agitation and Retardation Scale. MARS was developed to provide a measure of 19 abnormal behaviours associated with agitation and retardation in depressive disorders [20]. This scale included observable motor signs in five domains: trunk, limbs, eyes, face, and voice. Each item is scored from 0 to 4 depending on the presence or severity of symptoms. The MARS offers a rapid clinical assessment of 
TABLE 2: Studies exploring the physiopathology of psychomotor retardation.

\begin{tabular}{|c|c|c|c|c|}
\hline Authors & Sample (criteria) & Treatments & Methods & Results \\
\hline Bench et al. 1993 [72] & $\begin{array}{l}\text { Depressed }=40 \\
\quad(\mathrm{RDC}) \\
\text { Controls }=30\end{array}$ & $\begin{array}{l}\text { Antidepressant } \\
\text { Neuroleptic } \\
\text { Mood stabilizer }\end{array}$ & $\begin{array}{l}\text { SPECT } \\
\text { Item "retardation" SADS }\end{array}$ & $\begin{array}{l}\text { Negative correlation between } \\
\text { PMR and CBF in the LDPFC } \\
\text { and angular gyrus }\end{array}$ \\
\hline Hickie et al. 1995 [73] & $\begin{array}{c}\mathrm{MDD}=39 \\
\quad(\mathrm{RDC}) \\
\text { Controls = } 19\end{array}$ & $\begin{array}{l}\text { Antidepressant } \\
\text { ECT } \\
\text { Mood stabilizer }\end{array}$ & $\begin{array}{l}\text { MRI } \\
\text { Neuropsychological } \\
\text { assessment } \\
\text { (TMT, DSST) }\end{array}$ & $\begin{array}{l}\text { Association PMR/white } \\
\text { matter hyperintensities }\end{array}$ \\
\hline Hickie et al. 1999 [74] & $\begin{array}{l}\mathrm{MDD}=25 \\
\quad(\mathrm{RDC})\end{array}$ & NS & $\begin{array}{l}\text { SPECT } \\
\text { Reaction time }\end{array}$ & $\begin{array}{l}\text { Negative correlation between } \\
\text { reaction time and neostriatal } \\
\text { blood flow }\end{array}$ \\
\hline Videbech et al. 2002 [75] & $\begin{array}{c}\text { MDD = 42 } \\
(\mathrm{DSM} \text { IV }) \\
\text { Controls = } 15\end{array}$ & $\begin{array}{l}\text { Antidepressant } \\
\text { Neuroleptic } \\
\text { Mood stabilizer }\end{array}$ & $\begin{array}{l}\text { PET } \\
\text { MRI } \\
\text { SRRS }\end{array}$ & $\begin{array}{l}\text { Negative correlation between } \\
\text { SRRS and CBF in dorsolateral } \\
\text { and supraorbital prefrontal } \\
\text { cortices }\end{array}$ \\
\hline Naismith et al. 2002 [76] & $\begin{array}{c}\mathrm{MDD}=46 \\
(\mathrm{DSM} \text { IV) } \\
\text { Controls }=20\end{array}$ & Antidepressant & $\begin{array}{l}\text { SPECT } \\
\text { Stroop test }\end{array}$ & $\begin{array}{l}\text { Negative correlation between } \\
\text { PMR and blood flow in the } \\
\text { LDPFC and angular gyrus }\end{array}$ \\
\hline Walther et al. 2012 [77] & $\begin{array}{c}\text { MDD = } 20 \\
(\mathrm{DSM} \text { IV }) \\
\text { Controls = } 19\end{array}$ & $\begin{array}{l}\text { Antidepressant } \\
\text { Mood stabilizer } \\
\text { Benzodiazepine } \\
\text { Hypnotic }\end{array}$ & $\begin{array}{l}\text { MRI } \\
\text { Actigraphy }\end{array}$ & $\begin{array}{l}\text { Positive association between } \\
\text { activity level and CBF in the } \\
\text { right orbitofrontal cortex and } \\
\text { inverse association in the left } \\
\text { supplemental motor area }\end{array}$ \\
\hline Walther et al. 2012 [78] & $\begin{array}{c}\text { MDD = 21 } \\
(\text { DSM IV) } \\
\text { Controls = 21 }\end{array}$ & $\begin{array}{l}\text { Antidepressant } \\
\text { Mood stabilizer } \\
\text { Benzodiazepine } \\
\text { Hypnotic }\end{array}$ & $\begin{array}{l}\text { Diffusion tensor imaging } \\
\text { Actigraphy }\end{array}$ & $\begin{array}{l}\text { Negative association between } \\
\text { activity level and fractional } \\
\text { anisotropy underneath the left } \\
\text { primary motor cortex }\end{array}$ \\
\hline Bracht et al. 2012 [79] & $\begin{array}{c}\text { MDD = 21 } \\
(\text { DSM IV) } \\
\text { Controls = 21 }\end{array}$ & $\begin{array}{l}\text { Antidepressant } \\
\text { Mood stabilizer } \\
\text { Benzodiazepine } \\
\text { Hypnotic }\end{array}$ & $\begin{array}{l}\text { Diffusion tensor imaging } \\
\text { Actigraphy }\end{array}$ & $\begin{array}{l}\text { Alteration of white matter } \\
\text { organisation of rostral } \\
\text { anterior cingulate } \\
\text { cortex-presupplementary } \\
\text { motor area and } \\
\text { dLPFC-presupplementary } \\
\text { motor area pathways }\end{array}$ \\
\hline Shah et al. 1997 [80] & $\begin{array}{c}\text { MDD = } 15 \\
(\mathrm{DSM} \text { IV) } \\
\text { Controls }=15\end{array}$ & $\begin{array}{l}\text { Antidepressant } \\
\text { Benzodiazepine } \\
\text { Mood stabilizer }\end{array}$ & $\begin{array}{l}\text { IBZM-SPECT } \\
\text { CANTAB } \\
\text { HDRS }\end{array}$ & $\begin{array}{l}\text { Negative correlation between } \\
\text { IBZM binding and } \\
\text { psychomotor speed, but not } \\
\text { with the HDRS retardation } \\
\text { item }\end{array}$ \\
\hline Austin et al. 2000 [81] & $\begin{array}{c}\text { MEL }=7 \\
(\text { DSM IV) } \\
\text { Controls = } 30\end{array}$ & None & $\begin{array}{l}\text { Single administration of } \\
\text { the dopamine agonist } \\
\text { apomorphine: motor } \\
\text { and neuropsychological } \\
\text { tests before and after } \\
\text { injection }\end{array}$ & $\begin{array}{l}\text { No improvement of motor } \\
\text { and cognitive performance } \\
\text { after apomorphine injection }\end{array}$ \\
\hline Martinot et al. 2001 [82] & $\begin{array}{c}\text { MDD = } 12 \\
(\mathrm{DSM} \text { IV) } \\
\text { Controls }=7\end{array}$ & SRRI & $\begin{array}{l}\text { PET } \\
\text { MRI }\end{array}$ & $\begin{array}{l}\text { Retarded patients: reduction } \\
\text { of fluorodopa uptake in the } \\
\text { left caudate }\end{array}$ \\
\hline Meyer et al. 2006 [83] & $\begin{array}{l}\mathrm{MDD}=21 \\
(\mathrm{DSM} \text { IV) }\end{array}$ & None & $\begin{array}{l}\text { PET } \\
\text { Neuropsychological } \\
\text { assessment }\end{array}$ & $\begin{array}{l}\text { Correlation between putamen } \\
\mathrm{D}_{2} \text { binding potential and } \\
\text { motor performances }\end{array}$ \\
\hline Bajbouj et al. 2006 [84] & $\begin{array}{c}\text { MDD = 20 } \\
(\text { DSM IV) } \\
\text { Controls = 20 }\end{array}$ & None & $\begin{array}{l}\text { TMS } \\
\text { CORE }\end{array}$ & $\begin{array}{l}\text { Reduced GABAergic tone in } \\
\text { MDD }\end{array}$ \\
\hline Mitchell et al. 1996 [85] & $\begin{array}{c}\text { MEL }=20 \\
(\mathrm{DSM} \text { IV/CORE) } \\
\text { Controls }=20\end{array}$ & $\begin{array}{l}\text { Antidepressant } \\
\text { Neuroleptic }\end{array}$ & $\begin{array}{l}\text { Dexamethasone } \\
\text { suppression test } \\
\text { HDRS } \\
\text { CORE }\end{array}$ & $\begin{array}{l}\text { Negative correlation between } \\
\text { CORE score and cortisol level }\end{array}$ \\
\hline
\end{tabular}


TABLE 2: Continued.

\begin{tabular}{lclll}
\hline Authors & Sample (criteria) & Treatments & Methods & Results \\
\hline \multirow{3}{*}{ van Londen et al. 1997 [86] } & MDD $=48$ & & AVP concentrations & Correlation between AVP \\
& CSM III-R) & Benzodiazepine & Actimetry & concentrations and motor \\
& Controls $=30$ & & MADRS & activity during wakefulness \\
van Londen et al. 1998 [87] & MDD $=52$ & & AVP concentrations & Plasma AVP concentrations: \\
& ConM III-R) & Benzodiazepine & SRRS & severe retarded MDD $>$ \\
& Controls $=48$ & & MADRS & mild/no retarded MDD \\
\hline
\end{tabular}

AVP: arginine vasopressin; CANTAB: computerised psychometric testing battery; CBF: cerebral blood flow; DSM: Diagnostic and Statistic manual of Mental Disorders; DSST: digit symbol substitution test; ECT: electroconvulsivetherapy; IBZM-SPECT: iodo-methoxybenzamide-single photon emission tomography; HDRS: Hamilton Depression Rating Scale; LDLPFC: Left Dorsolateral Prefrontal Cortex; MEL: melancholic; MDD: major Depressive Disorder; MRI: magnetic resonance imaging; PET: positron emission Tomography; PMR: psychomotor retardation; RDC: Research Diagnosis Criteria; SADS: Schedule for Schizophrenia and Affective Disorder; SPECT: single photon emission computed tomography; SRRI: selective serotonin reuptake inhibitor; SRRS: Salpetrière Retardation Rating Scale; TMS: transcranial magnetic stimulation; TMT: trail making test.

motor signs but does not include items concerning noninteractiveness and cognitive slowing.

Although these three scales were developed to measure similar constructs, they have a number of differences. The SRRS attempts to directly tap into the mental life of the subject, specifically the presence or absence of perceived mental slowing. By contrast, the CORE scale does not rely on verbal responses from the patient, allowing it to be scored even in stuporous or mute patients [109].

\subsubsection{Objective Measures}

(a) Speech. Alterations in paralinguistic aspects of speech, associating changes in fluency and prosody, are a traditional finding in depressed patients. Earlier investigators simply used speech samples extracted from audiotape recordings of semistructured interviews or counting tasks $[22,23,28,29$, 32]. Szabadi et al. found a significant elongation of speech pause time in their depressed patients, whereas the phonation time remained constant. Other groups replicated this finding in larger samples of unipolar or bipolar depressed patients. More recent studies, using a sophisticated computer-driven acoustic measuring system, confirmed reduced prosody by analysing the variables measuring aspects of fundamental frequency [30, 31, 34, 35]. Moreover, differences between depressed and normal comparison groups have also been shown in articulation characteristics [33]. Several studies have found a strong correlation between change in clinical ratings of symptom severity and several key voice acoustic measures. These measures appear to be sensitive to both early symptomatic improvement and degree of response to therapeutic intervention and may be state-dependent indicators of depression $[23,34]$.

(b) Gross Motor Activity. Psychomotor abnormalities are manifest in various motor domains including alterations of gait, posture, or limb movement and have been investigated in patients by actigraphy, cinematography, or ground reaction forces [3]. Ratings of nonverbal behaviour in depressive states showed altered temporal segmentation of movements, increased brief repetitive body touching, and continuous hand-to-head and hand-to-hand touching [42]. Recordings of reaction times and velocity scaling during wrist flexion, using a hand-held rotation sensor, have been used to explore the subject's ability to increase movement velocity [98]. Actimetry is another relatively simple method of spontaneous motor activity exploration. Applied to depression it allows a quantitative and qualitative study of patterns of activity through different parameters distinguishing periods of rest and activity. Studies included in our review offer an analysis of the average level of activity and parameters of immobility for different periods [25]. Several authors have reported variations on the circadian expression of psychomotor symptoms in depression, and observed a general disorganization of motor activity, with a significant reduction in activity levels in the late morning, early afternoon, and early evening $[13,24-$ $26,97]$. In depressed patients, lower motor activity levels were associated with clinical ratings of retardation $(r=0.717, P<$ $0.05)$ and depression severity $(r=0.66, P<0.05)$ [25]. The study of the patient's environment (hospital setting instead of home environment) has influenced the type of daily activities and consequently the $24 \mathrm{~h}$ pattern of motor activity. Global motor activity has also been objectively analysed during locomotion. Spatiotemporal gait parameters were measured during overground walking at self-selected walking speed on a walkway. Compared to controls, depressed patients showed significantly lower gait velocity, reduced stride length, double limb support and cycle duration [36-39]. There was a significant correlation found between cadence and gait velocity in depressed patients $(r=0.51, P<0.05)$. These studies have failed to find a correlation between spatiotemporal gait parameters and clinical assessment of motor retardation or severity of depression.

(c) Fine Motor Activity. Sensitive instrumental measure of motor slowing may allow detection of motor system abnormalities that are not clinically observed.

(1) Drawing Tasks. Kinematic analysis of drawing and handwriting movements allows precise and objective studies of motor abnormalities in depression [44, 46-49]. These studies are based on computerised recording techniques (graphics tablet and a pressure-sensitive pen) to analyse motor parameters during the copying of simple or complex geometric figures. The instructions given to subjects included particular requirements for accuracy and speed of movement. Specific variables that allow a distinction between cognitive 


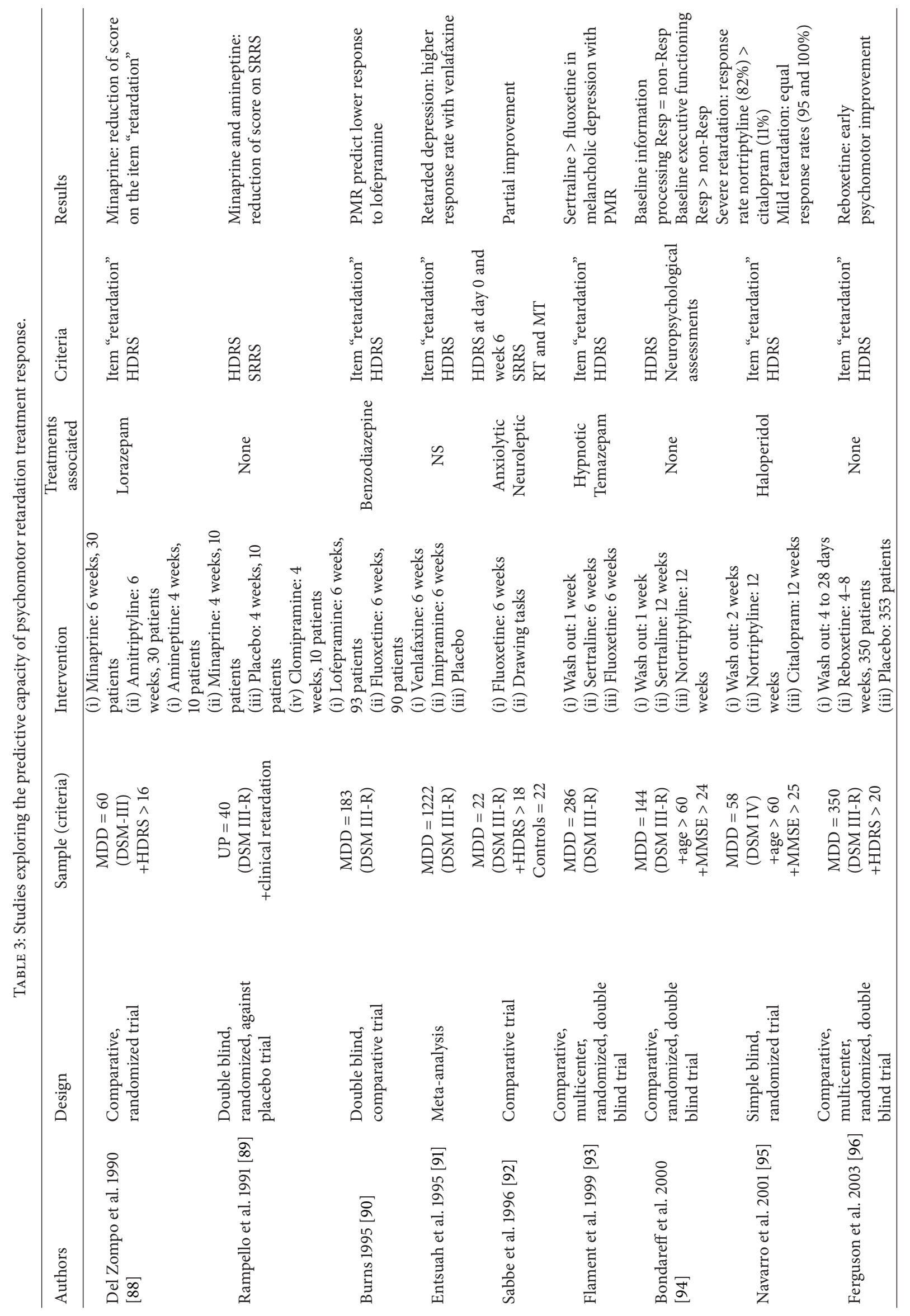




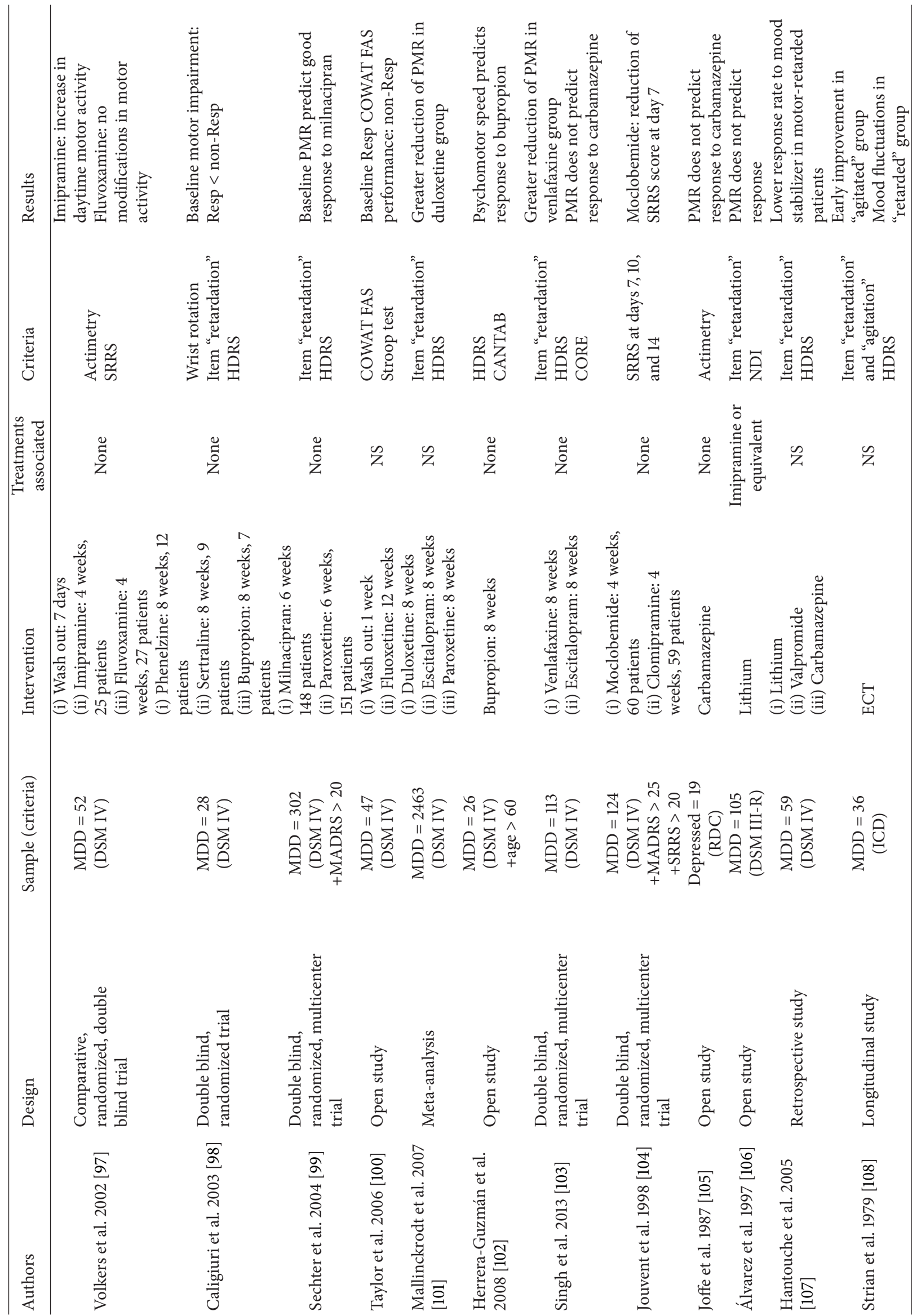




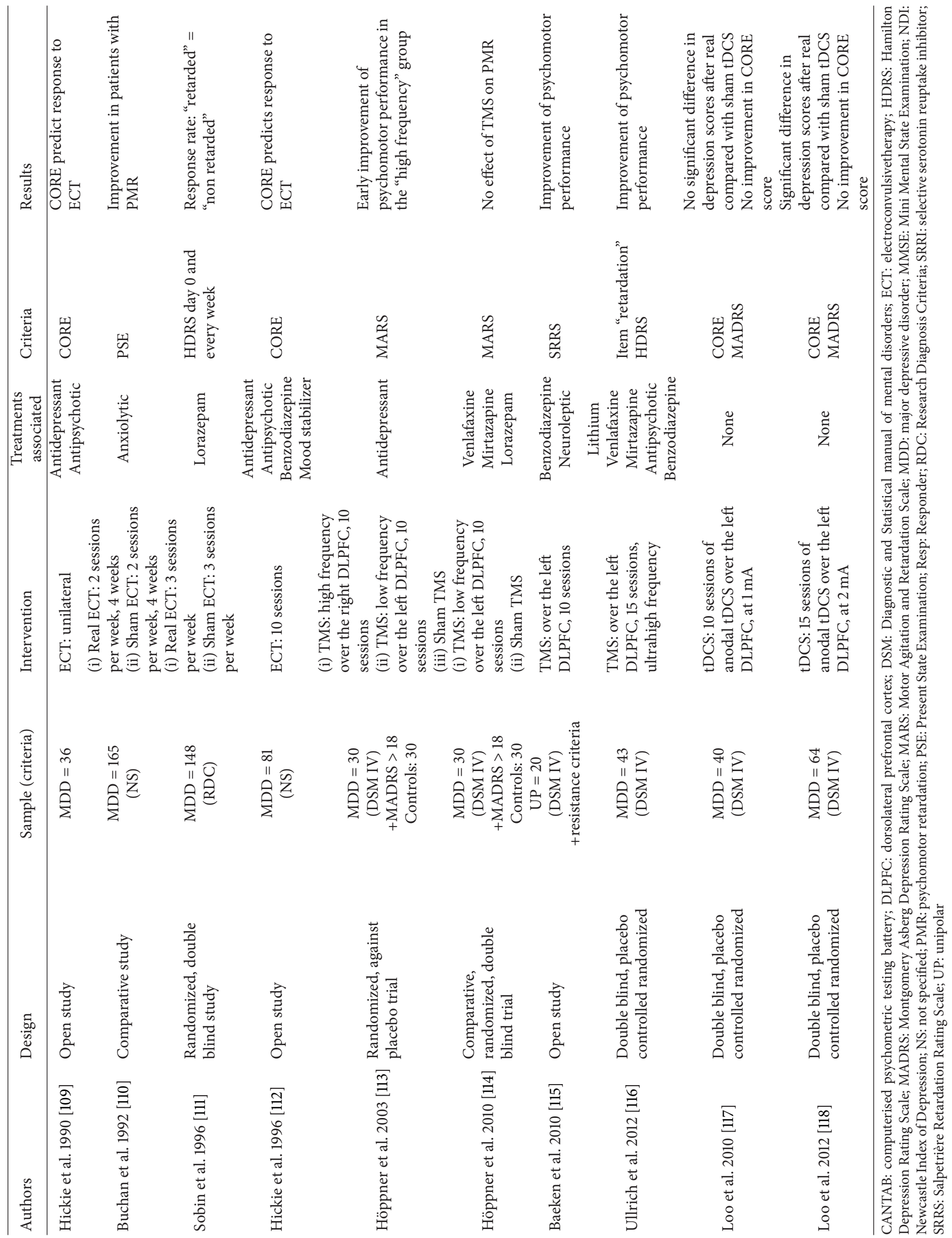


and motor processes included both initiation time and movement time. Motor slowing affects both the motor and cognitive processes, as reflected by an increase in motor and initiation time during simple and complex tasks [44, 46 , 47]. Furthermore, the melancholic patients were more severely affected than the nonmelancholic patients [47]. Another approach, based on the investigation of internally and externally cued movements, aimed to delineate psychotic major depression in the fine motor domain. Hoffstaedter et al. performed a computerised motor paradigm and reported that internally cued movements were more severely affected than externally cued reactions during major depressive disorder (MDD), suggesting specific impairments of visuospatial and attentional processing as cognitive aspects of psychomotor functioning [50].

(2) Eye Movements. Eye movement tasks constitute an interesting tool to investigate psychomotor functioning, through exploration of basic and high levels of motor control including spatial working memory, prediction, and response suppression. A number of studies have explored eye movements in groups of patients with major depression. These studies have reported the presence of intact reflexive saccades [52, 53], normal latencies and velocities for voluntary saccades, but increased durations [52], normal or slightly increased rates of response suppression errors, and reduced accuracy for memory-guided saccades [52]. In addition, one study has explored differences in eye movements between melancholic and nonmelancholic patients and showed in the melancholic patient greater intrasubject variability of latencies, lower peak saccade velocities, and reduced accuracy of the primary saccade [54].

(3) Facial Movements. Recordings of facial muscle electromyographic activity during the generation of affective imagery represents one promising strategy for examining motor deficits in depression [5]. In contrast to controls, depressed subjects showed significant reduced electromyographic patterns for happiness [51]. Retardation was documentable even though trained clinicians were unable to identify obvious clinical signs of motor retardation.

(d) Cognitive Measures. Slow ideation is a common subjective complaint in patients with motor retardation [59]. Different studies have sought to determine to what extent certain neuropsychological tests might be more specifically related to retardation than to general cognitive inefficiency $[55,56,58$, 63].

Reaction time methods have been used as a simple and objective index of PMR. Numerous studies have also demonstrated the independence of central (cognitive) and peripheral (motor) components of reaction time by separately measuring the time required to initiate a response (decision time) and the time required to carry out the motor activity to complete the response. Cornell et al. found a motor component to PMR in both melancholic and nonmelancholic groups, while only melancholic patients manifested an additional cognitive impairment [56]. Using the Nufferno speed test and the Gibson maze test, Blackburn observed a significant reduction of psychomotor speed in their depressed bipolar patients [55]. Bonin-Guillaume et al. [63] performed two reaction time experiments using an additive factor analysis and found that PMR associated with depression was limited to the components of response selection and motor adjustment.

Measurements of ideational retardation, and notably latency of response to the Rorschach plates and to simplified nonfigurative line drawings, have been proposed by Brebion et al. [59]. These authors have shown significant correlations between the latency of response and scores on the SRRS $(r=0.71, P<0.0005)$. Finally, a modified version of Posner's covert orientation of visual attention test, wich involves shifting of preparation for response from on side to another, was designed by Smith [58]. This author found that the time of maximal response preparation occurred later in depressive patients than in controls, and was strongly correlated with observable psychomotor retardation but not with depressive severity. Mental rotation, as a reflection of visuospatial cognitive operation, is another useful tool for assessing motor preparation. During ego-rotation and objectrotation tasks, involving the creation of a mental image of an object and its subsequent rotation, MDD patients exhibited specific deficits compared to controls [64].

\subsection{Factors Influencing PMR}

3.2.1. Influence of Age. In later life, age and depression may interact, resulting in a more pronounced retardation in geriatric patients. PMR occurs in atypical depression presentations in the elderly, such as subsyndromal depression [120] or depression-executive dysfunction syndrome [121]. These motor abnormalities differed from slowing due to normal aging in that only some information-processing stages were affected by age whereas all the processing stages were affected by age [27]. Furthermore, experimental studies have demonstrated that depressed geriatric patients exhibited PMR similar to younger adults $[34,48,122]$. Considering the presence and type of psychomotor disturbance may be an important psychopathologic feature that differentiates clinically distinct forms of juvenile MDD. Moreover, Leventhal et al. identified agitated and agitated-retarded depression as a specific phenotypic syndrome in young adults [123].

3.2.2. Influence of Sex. Studies of gender differences in the clinical presentation of depression have provided divergent results. While some authors found no clinical relevant gender differences in the prevalence of any psychomotor symptoms [124], other studies reported higher rates of retardation in males than females $[125,126]$. The discrepant findings between studies may relate to differences in methodology, sample sizes, and severity or nature of the depressive disorder.

3.2.3. Influence of Treatments. Pharmacological treatments can contribute to improve psychomotor functioning, but may also have disruptive effects, causing sedation or impairment in psychomotor and cognitive function. Benzodiazepine may 
affect the speed with which simple repetitive motor actions are performed [127] and impaired performances during a tapping task [128]. Clinical practice suggests that motor slowing is quite frequently found in patients treated with classical neuroleptics, although no effects or even improvements have been found [129].

\subsubsection{Influence of Depression Subtype}

(a) Melancholic Depression. In a series of articles devoted to the study of psychomotor disturbances during melancholic access, Parker et al. proposed PMR as a marker of an underlying neuropathological process specific for the melancholic depressive subtype $[21,119,130]$. The biological and clinical plausibility for this putative endophenotype include associations between psychomotor disturbances and hypothalamic-pituitary-adrenocortical axis dysfunction in depressed subjects, and parkinsonian movement deficits in melancholic patients $[7,85]$. Unfortunately, information on heritability, familial association, state-independence, and cosegregation of specific psychomotor disturbances are lacking [131]. Comparing melancholic and nonmelancholic samples, several researchers found that melancholic patients are more retarded during drawing or oculomotor tasks [47, 54], limb movements [68], or reaction time [56]. However, other authors failed to reproduce these results $[30,132]$.

Concerning melancholic depression with a psychotic feature, Parker et al. suggested that, in addition to the presence of delusions and/or hallucinations, the presence of psychomotor disturbances was the most consistently reported additional feature. Psychotic depression appears to be most specifically associated with profound noninteractiveness and severe agitation.

(b) Bipolar/Unipolar Depression. Psychomotor retardation is considered a robust feature distinguishing between bipolar and unipolar depression, supporting historical clinical description considering psychomotor disturbance as a cardinal feature of bipolar depression [8]. Nevertheless, several studies found no differences in rates of retardation between major depressive disorder and type 2 bipolar disorder samples, but rather significantly higher rates of agitation among the group with type 2 bipolar disorder $[133,134]$. PMR, diagnosed by clinical observation or experimental assessments, may have more relevance to bipolar type I depression.

3.3. Specificity of PMR in Depression. Psychomotor retardation can be present in different neuropsychiatric disorders, including schizophrenia or Parkinson's disease. For instance, experimental comparisons between depressive and schizophrenic patients have shown a different slowing structure, with a slowness in both motor and cognitive components in depressed patients, whereas the schizophrenic patients only exhibited a slowness in the cognitive component [66]. Similarly, patients with depression exhibit difficulties initiating movements in the absence of external cues, as patients with Parkinson's disease. Slowed motor activity and difficulties in self-initiating movements, common to melancholic depression, negative symptoms in schizophrenia, and Parkinson's disease, may reflect dysfunction within frontostriatal circuits [54].

Correlation analyses between motor signs and severity of depression indicate that some aspects of psychomotor slowing are related to state changes in depression [12] Szabadi et al. [28]. This notion is supported by positive effects of pharmacological treatments, leading to changes in depression rating scale scores significantly correlated with changes in motor performances Sabbe et al., Volkers et al. [92, 135]. However, other findings suggest that some components of motor retardation are trait characteristics in depression. For example, Caligiuri and Ellwanger [65] found specific abnormalities on a velocity scaling measure in bipolar depressed patients, compared with unipolar patients.

To date, the data available provide arguments in favour of the two hypotheses, and this question still remains to be investigated.

Our review of the literature illustrates the multiplicity of objective exploration of PMR in different areas of psychomotor functioning. These studies support the achievement of cognitive and motor functions involved in the production process of the movement. Correlations between objective measures and subjective appreciation of PMR based on clinical scales have led to conflicting results. These results may be related to differences in clinical expression of retardation or even to the existence of a subclinical slowdown not identifiable by the clinician. There are no published studies to our knowledge combining several techniques of PMR objective measures. The combination of different experimental techniques for measuring retardation with clinical assessments could offer an increased understanding of PMR in depression.

3.4. Neuropathology. The neurobiology of major depressive disorders has been associated with alterations in prefrontal and orbitofrontal cortices, anterior cingulate, amygdala, and the hippocampus $[136,137]$. Concerning the neurobiology of motor retardation in depression, some findings point to structural alterations of the basal ganglia circuits [76]. Although the association between Parkinson's disease and bradyphrenia is uncertain, similarities have been drawn between the motor slowness of PMR in some major depressed patients and bradykinesia in Parkinson's disease and consequently to the possibility that the two phenomena may share some common underlying pathology $[33,65,67]$. The basal ganglia system constitutes, therefore, a possible candidate as a site of motor dysfunction common to these two disorders. Various experimental works have suggested that some aspects of motor deficits are equally present in the two pathologies. In one study two groups of patients exhibited similar deficits in self-initiated movements [67], in the programming of movement velocity $[65,68]$, or in articulation [33]. Moreover, patients with MDD and PMR were shown to have reduced extracellular dopamine in caudate and putamen. Martinot et al. assessed presynaptic dopamine function by using positron emission tomography (PET) and 6-[18F] fluorodopa in depressed patients and healthy subjects. [18F] DOPA 
uptake Ki values in the left caudate were significantly lower in patients with psychomotor retardation than in comparison subjects [82]. Meyer et al. obtained concordant results, and observed an elevation in D2 binding in caudate and putamen, measured with [11C] raclopride PET [83]. Shah et al. reported decreased dopamine function, as indexed by increased binding of the dopamine D 2/3 ligand 1-123-IBZM, in the right striatum if patients with major depression [80]. Conversely, one study yielded no evidence to support the hypothesis that patients with psychomotor retardation have decreased dopaminergic function [81]. Beside dopaminergic dysregulation, some studies have linked psychomotor symptoms and noradrenergic transmission [138]. Evidence of clinical activity of antidepressant drugs with noradrenergic action supported this hypothesis. The interaction of GABAergic system and psychomotor retardation was supported by Bajbouj et al. who found a strong correlation between psychomotor retardation measured with the CORE questionnaire and transcranial magnetic stimulation (TMS) based measures of cortical excitability [84].

Neuroimaging studies provide strong evidence for an involvement of brain structures associated with initiation, planification, and motor control of behaviour in clinical psychomotor symptoms. Negative correlations between cerebral blood flow and clinically rated PMR were found in the dorsolateral prefrontal cortex, orbitofrontal cortex, and angular gyrus $[72,75,76]$. Similarly, longer reaction times were associated with reduced cerebral blood flow (CBF) increase in the striatum during a simple motor task [74]. In addition, structural imaging studies have indicated a negative correlation between white matter hyper intensities and psychomotor speed [73]. Walther et al. linked PMR to $\mathrm{CBF}$ of the supplemental motor area, suggesting disbalanced motor control in MDD [77, 78]. More recently, studies using diffusion tensor imaging measures of white matter pathways connecting these regions demonstrated altered white matter organisation of rostral anterior cingulate cortex-presupplementary motor area and dLPFC-presupplementary motor area pathways [78].

3.5. Treatments. Several studies suggest that PMR measures may provide prognostic information concerning antidepressant response. The results of clinical rating suggest that PMR can be used as marker for antidepressant response. Flament et al. found that their patients with motor retardation responded less favourably to 6 weeks of fluoxetine or sertraline treatment compared to nonmotor retarded sample of patients [93]. Sechter et al. found that baseline retardation predicted a response to milnacipran. Similarly designed studies found that PMR failed to predict a response to selective serotonin reuptake (SRRI) $[90,99]$. Experimental assessments of PMR support his predictive value. In an open-treatment medication study, Caligiuri et al. demonstrated that a quantitative measure of motor programming may be a useful predictor of antidepressant nonresponse [98]. Concerning information processing speed, Dunkin et al. found that patients whose symptoms did not remit following 8 weeks of fluoxetine treatment had impaired baseline pretreatment functioning [139].
Conversely, Taylor et al. suggest a deficit in psychomotor speed distinguishing SSRI nonresponse [100].

The impact of different pharmacological treatments on motor symptoms in depressed patients was examined using clinical scales or experimental assessment. Ferguson et al. combined the data of 4 clinical studies and found a significant improvement of PMR in patients following 4 weeks of reboxetine treatment [96]. In their meta-analysis, Entsuah et al. reported beneficial effects of venlafaxine [91]. The preferential efficacy of venlafaxine for psychomotor retardation symptoms was recently supported by Singh et al. in a study comparing the clinical effects of venlafaxine and escitalopram in MDD [103]. Comparing clinical response, Del Zompo et al. observed that minaprine was more effective than tricyclic antidepressant on PMR in depressed patients [88]. Assessing the therapeutic efficacy of various antidepressants (minaprine, amineptines and clomipramine) Rampello et al. obtained convergent results [89]. In a double blind study, Bondareff et al. observed similar response rate to sertraline and nortriptyline while Navarro et al. found a better response rate for nortriptyline than citalopram in an elderly depressed patient $[94,95]$. In addition, Sabbe et al. found that the effect of fluoxetine on the motor components of drawing were relatively low [92]. Unfortunately we failed to find available data on effects of psychotherapy on PMR.

The latency of action of antidepressive medications or their contraindication justifies the use of electroconvulsive therapy (ECT) in first intention in severe depressive states where the prognosis is committed. Joining the notion of severity, depressions with delusions and those with catatonic symptoms are preferential indications of ECT, as well as melancholic depression, due to gravity or clinical criteria. The analysis of the association of specific symptom profiles with ECT outcome indicates that the psychotic feature, older age, and psychomotor disturbances were predictive of greater response $[108,109,112]$.

A combined analysis of randomized controlled trials of ECT versus simulated ECT showed that real ECT had a therapeutic advantage, specifically among patients with retardation and/or delusions [110]. Nevertheless, in 2 randomized controlled trials, involving 148 patients, Sobin et al. investigated the utility of depression subtypes in predicting ECT response and concluded that ECT was a treatment option for patients with major depression; however, neither the presence of psychotic features, retardation, and/or agitation predicted superior response [111].

More responsible for the variation of results among studies on ECT can be, respectively, the number of ECT sessions applied, the methodological weakness of some studies that did not specify the electrical parameters of the bilateral ECT and/or unilateral ECT.

Only four studies have investigated whether HF-rTMS treatments affect psychomotor symptoms [113-115]. Baeken et al. did not report any significant relationship between psychomotor symptoms and clinical response. Moreover they observed a reduction of psychomotor disturbances after the treatment, independent of age, sex, and duration of illness [115]. Hoppner et al. obtained convergent results, with a reduction of the score on the MARS scale after treatment 
[113]. In a sample of severely depressed patients, Ullrich et al. reported a significant improvement of processing speed performance, which covaried with the improvement of psychomotor retardation, after 3 weeks of ultrahigh frequency rTMS [116].

Concerning behavioural facilitatory effects of transcranial direct current stimulation (tDCS), Loo et al. failed to predict the antidepressant response using the CORE measure in two subsequent studies. However, they obtained positive results on depressive symptomatology, with a greater reduction in MADRS scores after real versus sham stimulations after applying 15 sessions of anodal tDCS at $2 \mathrm{~mA}$ to 64 unipolar and bipolar depressed patients $[117,118]$.

\section{Conclusion}

Psychomotor retardation is a central feature of depression that can have clinical and therapeutic implications. This includes both motor and cognitive impairments, affecting speech, motility, and ideation. These symptoms may severely impact patient's psychosocial functioning $[140,141]$ and are closely linked with severity of depression [9].

The still fragmentary data on the status of PMR in depression confirm the need for further quantitative and qualitative investigations, particularly concerning its relationship with motivation and emotions.

The study of the dynamic interactions of systems governing motor, cognitive, and emotional aspects of movement production is likely to enrich the understanding of the neurobiological substrates of depression and its treatment.

\section{Acknowledgment}

The authors are grateful to Richard Medeiros-Medical Editor of Medical Editing International—for editing the final paper.

\section{References}

[1] A. P. Association, Diagnostic and Statistical Manual of Mental Disorders DSM-IV-TR, Amer Psychiatric, 4th edition, 2000.

[2] E. Kraepelin, La Folie Maniaque-Dépressive, Editions Jérôme Millon, 1993.

[3] C. Sobin and H. A. Sackeim, "Psychomotor symptoms of depression," The American Journal of Psychiatry, vol. 154, no. 1, pp. 4-17, 1997.

[4] D. Widlöcher, Le Ralentissement Dépressif, Presses Universitaires de France, 1983.

[5] J. F. Greden and B. J. Carroli, "Psychomotor function in affective disorders: an overview of new monitoring techniques," The American Journal of Psychiatry, vol. 138, no. 11, pp. 1441-1448, 1981.

[6] G. E. Berrios, The History of Mental Symptoms: Descriptive Psychopathology Since the Nineteenth Century, Cambridge University Press, 1996.

[7] G. Parker and D. Hadzi-Pavlovic, Melancholia: A Disorder of Movement and Mood: A Phenomenological and Neurobiological Review, Cambridge University Press, 1996.
[8] F. Goodwin and K. R. Jamison, Manic Depressive Illness, Oxford University Press, 1990.

[9] J. C. Nelson and D. S. Charney, "The symptoms of major depressive illness," The American Journal of Psychiatry, vol. 138, no. 1, pp. 1-13, 1981.

[10] N. Dantchev and D. J. Widlöcher, "The measurement of retardation in depression," The Journal of Clinical Psychiatry, vol. 59, no. 14, pp. 19-25, 1998.

[11] R. K. Day, "Psychomotor agitation: poorly defined and badly measured," Journal of Affective Disorders, vol. 55, no. 2-3, pp. 8998, 1999.

[12] A. P. R. Moffot, "Diurnal variation of mood and neuropsychological function in major depression with melancholia," Journal of Affective Disorders, vol. 32, no. 4, pp. 257-269, 1994.

[13] M. R. Lemke, A. Broderick, M. Zeitelberger, and W. Hartmann, "Motor activity and daily variation of symptom intensity in depressed patients," Neuropsychobiology, vol. 36, no. 2, pp. 5761, 1997.

[14] A. Scheurich, A. Fellgiebel, I. Schermuly, S. Bauer, R. Wölfges, and M. J. Müller, "Experimental evidence for a motivational origin of cognitive impairment in major depression," Psychological Medicine, vol. 38, no. 2, pp. 237-246, 2008.

[15] O. Tucha, S. Aschenbrenner, P. Eichhammer et al., "The impact of tricyclic antidepressants and selective serotonin re-uptake inhibitors on handwriting movements of patients with depression," Psychopharmacology, vol. 159, no. 2, pp. 211-215, 2002.

[16] R. P. Snaith, "Hamilton rating scale for depression," The British Journal of Psychiatry, vol. 131, pp. 431-432, 1977.

[17] F. Peyre, R. Martinez, M. Calache, H. Verdoux, and M. Bourgeois, "New validation of the Montgomery and Asberg Depression Scale (MADRS) on a sample of 147 hospitalized depressed patients," Annales Medico-Psychologiques, vol. 147, no. 7, pp. 762-767, 1989.

[18] M. Roth, C. Gurney, and C. Q. Mountjoy, “The Newcastle rating scales," Acta Psychiatrica Scandinavica, vol. 68 , no. 310 , pp. $42-$ 54, 1983.

[19] R. Jouvent, D. Frechette, F. Binoux, S. Lancrenon, and A. des Lauriers, "Retardation in depressive states: elaboration of a quantitative rating scale," Encephale, vol. 6, no. 1, pp. 41-58, 1980.

[20] C. Sobin, L. Mayer, and J. Endicott, "The motor agitation and retardation scale: a scale for the assessment of motor abnormalities in depressed patients," Journal of Neuropsychiatry and Clinical Neurosciences, vol. 10, no. 1, pp. 85-92, 1998.

[21] G. Parker, D. Hadzi-Pavlovic, M.-P. Austin et al., "Sub-typing depression, I. Is psychomotor disturbance necessary and sufficient to the definition of melancholia?" Psychological Medicine, vol. 25, no. 4, pp. 815-823, 1995.

[22] P. Hardy, R. Jouvent, and D. Widlocher, "Speech pause time and the retardation rating scale for depression (ERD). Towards a reciprocal validation," Journal of Affective Disorders, vol. 6, no. 1, pp. 123-127, 1984.

[23] G. M. A. Hoffmann, J. C. Gonze, and J. Mendlewicz, "Speech pause time as a method for the evaluation of psychomotor retardation in depressive illness," The British Journal of Psychiatry, vol. 146, pp. 535-538, 1985.

[24] N. Raoux, "Circadian pattern of motor activity in major depressed patients undergoing antidepressant therapy: relationship between actigraphic measures and clinical course," Psychiatry Research, vol. 52, no. 1, pp. 85-98, 1994.

[25] N. Dantchev, J.-F. Allilaire, and N. Raoux, "Significance of studies of motor activity in depression," Annales MedicoPsychologiques, vol. 150, no. 2-3, pp. 206-210, 1992. 
[26] S. Royant-Parola, A. A. Borbely, and I. Tobler, "Monitoring of long-term motor activity in depressed patients," The British Journal of Psychiatry, vol. 149, pp. 288-293, 1986.

[27] S. Bonin-Guillaume, L. Sautel, C. Demattei, E. Jouve, and O. Blin, "Validation of the Retardation Rating Scale for detecting depression in geriatric inpatients," International Journal of Geriatric Psychiatry, vol. 22, no. 1, pp. 68-76, 2007.

[28] E. Szabadi, C. M. Bradshaw, and J. A. O. Besson, "Elongation of pause time in speech: a simple, objective measure of motor retardation in depression," The British Journal of Psychiatry, vol. 129, no. 12, pp. 592-597, 1976.

[29] J. F. Greden, A. A. Albala, and I. A. Smokler, "Speech pause time: a marker of psychomotor retardation among endogenous depressives," Biological Psychiatry, vol. 16, no. 9, pp. 851-859, 1981.

[30] A. Nilsonne, "Acoustic analysis of speech variables during depression and after improvement," Acta Psychiatrica Scandinavica, vol. 76, no. 3, pp. 235-245, 1987.

[31] A. Nilsonne, "Speech characteristics as indicators of depressive illness," Acta Psychiatrica Scandinavica, vol. 77, no. 3, pp. 253263, 1988.

[32] K. S. Kuny St. and H. H. Stassen, "Speaking behavior and voice sound characteristics in depressive patients during recovery," Journal of Psychiatric Research, vol. 27, no. 3, pp. 289-307, 1993.

[33] A. J. Flint, S. E. Black, I. Campbell-Taylor, G. F. Gailey, and C. Levinton, "Abnormal speech articulation, psychomotor retardation, and subcortical dysfunction in major depression," Journal of Psychiatric Research, vol. 27, no. 3, pp. 309-319, 1993.

[34] M. Alpert, E. R. Pouget, and R. R. Silva, "Reflections of depression in acoustic measures of the patient's speech," Journal of Affective Disorders, vol. 66, no. 1, pp. 59-69, 2001.

[35] M. Cannizzaro, B. Harel, N. Reilly, P. Chappell, and P. J. Snyder, "Voice acoustical measurement of the severity of major depression," Brain and Cognition, vol. 56, no. 1, pp. 30-35, 2004.

[36] T. Hergueta, F. Delgado, and Y. Lecrubier, "Quantitative videoanalysis of gait in depressed inpatients," European Neuropsychopharmacology, vol. 6, supplement 4, pp. S4-S100, 1996.

[37] M. R. Lemke, T. Wendorff, B. Mieth, K. Buhl, and M. Linnemann, "Spatiotemporal gait patterns during over ground locomotion in major depression compared with healthy controls," Journal of Psychiatric Research, vol. 34, no. 4-5, pp. 277-283, 2000.

[38] J. M. Hausdorff, C.-K. Peng, A. L. Goldberger, and A. L. Stoll, "Gait unsteadiness and fall risk in two affective disorders: a preliminary study," BMC Psychiatry, vol. 4, article no. 39, 2004.

[39] Y. Lecrubier, "Physical components of depression and psychomotor retardation," The Journal of Clinical Psychiatry, vol. 67, supplement 6, pp. 23-26, 2006.

[40] A. C. Volkers, J. H. M. Tulen, W. W. Van Den Broek, J. A. Bruijn, J. Passchier, and L. Pepplinkhuizen, "Motor activity and autonomic cardiac functioning in major depressive disorder," Journal of Affective Disorders, vol. 76, no. 1-3, pp. 23-30, 2003.

[41] G. L. Iverson, "Objective assessment of psychomotor retardation in primary care patients with depression," Journal of Behavioral Medicine, vol. 27, no. 1, pp. 31-37, 2004.

[42] M. R. Lemke and M. Schleidt, "Temporal segmentation of human short-term behavior in everyday activities and interview sessions," Naturwissenschaften, vol. 86, no. 6, pp. 289-292, 1999.

[43] S. Aybek, A. Berney, A. Salarian, S. Valloton, K. Aminian, and F. J. G. Vingerhoets, "Objective evaluation of gait parameters and psychomotor retardation in major depression," in Proceedings of the 2nd International Congress on Gait \& Mental Function, 2008.
[44] J. J. M. van Hoof, W. Hulstijn, H. Van Mier, and M. Pagen, "Figure drawing and psychomotor retardation: preliminary report," Journal of Affective Disorders, vol. 29, no. 4, pp. 263-266, 1993.

[45] B. Sabbe, W. Hulstijn, J. van Hoof, and F. Zitman, "Fine motor retardation and depression," Journal of Psychiatric Research, vol. 30, no. 4, pp. 295-306, 1996.

[46] B. Sabbe, W. Hulstijn, J. van Hoof, H. G. Tuynman-Qua, and F. Zitman, "Retardation in depression: assessment by means of simple motor tasks," Journal of Affective Disorders, vol. 55, no. 1, pp. 39-44, 1999.

[47] M. P. B. I. Pier, W. Hulstijn, and B. G. C. Sabbe, "Differential patterns of psychomotor functioning in unmedicated melancholic and nonmelancholic depressed patients," Journal of Psychiatric Research, vol. 38, no. 4, pp. 425-435, 2004.

[48] M. P. B. I. Pier, W. Hulstijn, and B. G. C. Sabbe, "Psychomotor retardation in elderly depressed patients," Journal of Affective Disorders, vol. 81, no. 1, pp. 73-77, 2004.

[49] R. Mergl, G. Juckel, J. Rihl et al., "Kinematical analysis of handwriting movements in depressed patients," Acta Psychiatrica Scandinavica, vol. 109, no. 5, pp. 383-391, 2004.

[50] F. Hoffstaedter, J. Sarlon, C. Grefkes, and S. B. Eickhoff, "Internally vs. externally triggered movements in patients with major depression," Behavioural Brain Research, vol. 228, no. 1, pp. 125-132, 2012.

[51] G. E. Schwartz, P. L. Fair, and P. Salt, "Facial imagery and inagery in depression: an electromyographic study," Psychosomatic Medicine, vol. 38, no. 5, pp. 337-347, 1976.

[52] J. A. Sweeney, M. H. Strojwas, J. J. Mann, and M. E. Thase, "Prefrontal and cerebellar abnormalities in major depression: evidence from oculomotor studies," Biological Psychiatry, vol. 43, no. 8, pp. 584-594, 1998.

[53] R. Mahlberg, B. Steinacher, A. Mackert, and K.-M. Flechtner, "Basic parameters of saccadic eye movements-differences between unmedicated schizophrenia and affective disorder patients," European Archives of Psychiatry and Clinical Neuroscience, vol. 251, no. 5, pp. 205-210, 2001.

[54] C. Winograd-Gurvich, N. Georgiou-Karistianis, P. B. Fitzgerald, L. Millist, and O. B. White, "Ocular motor differences between melancholic and non-melancholic depression," Journal of Affective Disorders, vol. 93, no. 1-3, pp. 193-203, 2006.

[55] I. M. Blackburn, "Mental and psychomotor speed in depression and mania," The British Journal of Psychiatry, vol. 126, no. 4, pp. 329-335, 1975.

[56] D. G. Cornell, R. Suarez, and S. Berent, "Psychomotor retardation in melancholic and nonmelancholic depression: cognitive and motor components," Journal of Abnormal Psychology, vol. 93, no. 2, pp. $150-157,1984$.

[57] M. J. Smith, G. Brébion, J.-P. Banquet, and J.-F. Allilaire, "Experimental evidence for two dimensions of cognitive disorders in depressives," Journal of Psychiatric Research, vol. 28, no. 4, pp. 401-411, 1994.

[58] G. Brébion, “Retardation of mentation in depressives: posner's covert orientation of visual attention test," Journal of Affective Disorders, vol. 35, no. 3, pp. 107-115, 1995.

[59] G. Brebion, M. J. Smith, and J. F. Allilaire, "Psychometric characteristics of ideational retardation in depressives," British Journal of Clinical Psychology, vol. 34, no. 3, pp. 371-381, 1995.

[60] G. Brébion, M. J. Smith, and D. Widlocher, "Discrimination and response bias in memory: effects of depression severity and psychomotor retardation," Psychiatry Research, vol. 70, no. 2, pp. 95-103, 1997. 
[61] S. Lemelin, P. Baruch, A. Vincent, L. Laplante, J. Everett, and P. Vincent, "Deficient distractor inhibition or processing resource deficit?" Journal of Nervous and Mental Disease, vol. 184, no. 2, pp. 114-121, 1996.

[62] S. Lemelin and P. Baruch, "Clinical psychomotor retardation and attention in depression," Journal of Psychiatric Research, vol. 32, no. 2, pp. 81-88, 1998.

[63] S. Bonin-Guillaume, T. Hasbroucq, and O. Blin, "Psychomotor retardation associated to depression differs from that of normal aging," Psychologie et NeuroPsychiatrie du Vieillissement, vol. 6, no. 2, pp. 137-144, 2008.

[64] J. Chen, L. Yang, W. Ma et al., "Ego-rotation and object-rotation in major depressive disorder," Psychiatry Research, vol. 209, no. 1, pp. 32-39, 2013.

[65] M. P. Caligiuri and J. Ellwanger, "Motor and cognitive aspects of motor retardation in depression," Journal of Affective Disorders, vol. 57, no. 1-3, pp. 83-93, 2000.

[66] J. J. M. van Hoof, B. J. M. Jogems-Kosterman, B. G. C. Sabbe, F. G. Zitman, and W. Hulstijn, "Differentiation of cognitive and motor slowing in the Digit Symbol Test (DST): differences between depression and schizophrenia," Journal of Psychiatric Research, vol. 32, no. 2, pp. 99-103, 1998.

[67] D. Rogers, A. J. Lees, and E. Smith, "Bradyphrenia in Parkinson's disease and psychomotor retardation in depressive illness: an experimental study," Brain, vol. 110, no. 3, pp. 761-776, 1987.

[68] M. A. Rogers, J. L. Bradshaw, J. G. Phillips, and E. Chiu, "Reliance on external cues during serial sequential movement in major depression," Journal of Neurology Neurosurgery and Psychiatry, vol. 69, no. 2, pp. 237-239, 2000.

[69] F. El Massioui, J. Everett, M.-T. Martin, R. Jouvent, and D. Widlöcher, "Attention deficits in depression: an electrophysiological marker," NeuroReport, vol. 7, no. 15-17, pp. 2483-2486, 1996.

[70] F. Bange and N. Bathien, "Visual cognitive dysfunction in depression: an event-related potential study," Electroencephalography and Clinical Neurophysiology, vol. 108, no. 5, pp. 472-481, 1998.

[71] D. Schrijvers, E. R. A. De Bruijn, Y. J. Maas, P. Vancoillie, W. Hulstijn, and B. G. C. Sabbe, "Action monitoring and depressive symptom reduction in major depressive disorder," International Journal of Psychophysiology, vol. 71, no. 3, pp. 218-224, 2009.

[72] C. J. Bench, L. K. J. Friston, R. G. Brown, R. S. J. Frackowiak, and R. J. Dolan, "Regional cerebral blood flow in depression measured by positron emission tomography: the relationship with clinical dimensions," Psychological Medicine, vol. 23, no. 3, pp. 579-590, 1993.

[73] I. Hickie, E. Scott, P. Mitchell, K. Wilhelm, M.-P. Austin, and B. Bennett, "Subcortical hyperintensities on magnetic resonance imaging: clinical correlates and prognostic significance in patients with severe depression," Biological Psychiatry, vol. 37, no. 3, pp. 151-160, 1995.

[74] I. Hickie, P. Ward, E. Scott et al., "Neo-striatal rCBF correlates of psychomotor slowing in patients with major depression," Psychiatry Research, vol. 92, no. 2-3, pp. 75-81, 1999.

[75] P. Videbech, B. Ravnkilde, T. H. Pedersen et al., “The Danish PET/depression project: clinical symptoms and cerebral blood flow. A regions-of-interest analysis," Acta Psychiatrica Scandinavica, vol. 106, no. 1, pp. 35-44, 2002.

[76] S. Naismith, I. Hickie, P. B. Ward et al., "Caudate nucleus volumes and genetic determinants of homocysteine metabolism in the prediction of psychomotor speed in older persons with depression," The American Journal of Psychiatry, vol. 159, no. 12, pp. 2096-2098, 2002.

[77] S. Walther, O. Höfle, A. Federspiel et al., "Neural correlates of disbalanced motor control in major depression," Journal of Affective Disorders, vol. 136, no. 1-2, pp. 124-133, 2012.

[78] S. Walther, S. Hügli, O. Höfle et al., "Frontal white matter integrity is related to psychomotor retardation in major depression," Neurobiology of Disease, vol. 47, no. 1, pp. 13-19, 2012.

[79] T. Bracht, A. Federspiel, S. Schnell et al., "Cortico-cortical white matter motor pathway microstructure is related to psychomotor retardation in major depressive disorder," Plos One, vol. 7, no. 12, Article ID e52238, 2012.

[80] P. J. Shah, A. D. Ogilvie, G. M. Goodwin, and K. P. Ebmeier, "Clinical and psychometric correlates of dopamine $\mathrm{D}_{2}$ binding in depression," Psychological Medicine, vol. 27, no. 6, pp. 12471256, 1997.

[81] M.-P. Austin, P. Mitchell, D. Hadzi-Pavlovic et al., "Effect of apomorphine on motor and cognitive function in melancholic patients: a preliminary report," Psychiatry Research, vol. 97, no. 2-3, pp. 207-215, 2000.

[82] M.-L. P. Martinot, V. Bragulat, E. Artiges et al., "Decreased presynaptic dopamine function in the left caudate of depressed patients with affective flattening and psychomotor retardation," The American Journal of Psychiatry, vol. 158, no. 2, pp. 314-316, 2001.

[83] J. H. Meyer, H. E. McNeely, S. Sagrati et al., "Elevated putamen $\mathrm{D}_{2}$ receptor binding potential in major depression with motor retardation: an $\left[{ }^{11} \mathrm{C}\right]$ raclopride positron emission tomography study," The American Journal of Psychiatry, vol. 163, no. 9, pp. 1594-1602, 2006.

[84] M. Bajbouj, S. H. Lisanby, U. E. Lang, H. Danker-Hopfe, I. Heuser, and P. Neu, "Evidence for impaired cortical inhibition in patients with unipolar major depression," Biological Psychiatry, vol. 59, no. 5, pp. 395-400, 2006.

[85] P. Mitchell, D. Hadzi-Pavlovic, G. Parker et al., "Depressive psychomotor disturbance, cortisol, and dexamethasone," Biological Psychiatry, vol. 40, no. 10, pp. 941-950, 1996.

[86] L. van Londen, J. G. Goekoop, G. M. J. Van Kempen et al., "Plasma levels of arginine vasopressin elevated in patients with major depression," Neuropsychopharmacology, vol. 17, no. 4, pp. 284-292, 1997.

[87] L. van Londen, G. A. Kerkhof, F. Van Den Berg et al., "Plasma arginine vasopressin and motor activity in major depression," Biological Psychiatry, vol. 43, no. 3, pp. 196-204, 1998.

[88] M. Del Zompo, F. Bernardi, C. Burrai, and A. Bocchetta, "A double-blind study of minaprine versus amitriptyline in major depression," Neuropsychobiology, vol. 24, no. 2, pp. 79-83, 1990.

[89] L. Rampello, G. Nicoletti, and R. Raffaele, "Dopaminergic hypothesis for retarded depression: a symptom profile for predicting therapeutical responses," Acta Psychiatrica Scandinavica, vol. 84, no. 6, pp. 552-554, 1991.

[90] R. A. Burns, "Predictors of response to amine-specific antidepressants," Journal of Affective Disorders, vol. 35, no. 3, pp. 97106, 1995.

[91] R. Entsuah, G. V. Upton, and R. Rudolph, "Efficacy of venlafaxine treatment in depressed patients with psychomotor retardation or agitation: a meta-analysis," Human Psychopharmacology, vol. 10, no. 3, pp. 195-200, 1995.

[92] B. Sabbe, J. van Hoof, W. Hulstijn, and F. Zitman, "Changes in fine motor retardation in depressed patients treated with fluoxetine," Journal of Affective Disorders, vol. 40, no. 3, pp. 149$157,1996$. 
[93] M. F. Flament, R. M. Lane, R. Zhu, and Z. Ying, "Predictors of an acute antidepressant response to fluoxetine and sertraline," International Clinical Psychopharmacology, vol. 14, no. 5, pp. 259-275, 1999.

[94] W. Bondareff, M. Alpert, A. J. Friedhoff, E. M. Richter, C. M. Clary, and E. Batzar, "Comparison of sertraline and nortriptyline in the treatment of major depressive disorder in late life," The American Journal of Psychiatry, vol. 157, no. 5, pp. 729-736, 2000.

[95] V. Navarro, C. Gastó, X. Torres, T. Marcos, and L. Pintor, "Citalopram versus nortriptyline in late-life depression: a 12week randomized single-blind study," Acta Psychiatrica Scandinavica, vol. 103, no. 6, pp. 435-440, 2001.

[96] J. M. Ferguson, K. A. Wesnes, and G. E. Schwartz, "Reboxetine versus paroxetine versus placebo: effects on cognitive functioning in depressed patients," International Clinical Psychopharmacology, vol. 18, no. 1, pp. 9-14, 2003.

[97] A. C. Volkers, J. H. M. Tulen, W. W. Van Den Broek, J. A. Bruijn, J. Passchier, and L. Pepplinkhuizen, "24-Hour motor activity after treatment with imipramine or fluvoxamine in major depressive disorder," European Neuropsychopharmacology, vol. 12, no. 4, pp. 273-278, 2002.

[98] M. P. Caligiuri, V. Gentili, S. Eberson, J. Kelsoe, M. Rapaport, and J. C. Gillin, "A quantitative neuromotor predictor of antidepressant non-response in patients with major depression," Journal of Affective Disorders, vol. 77, no. 2, pp. 135-141, 2003.

[99] D. Sechter, P. Vandel, E. Weiller, N. Pezous, F. Cabanac, and A. Tournoux, "A comparative study of milnacipran and paroxetine in outpatients with major depression," Journal of Affective Disorders, vol. 83, no. 2-3, pp. 233-236, 2004.

[100] B. P. Taylor, G. E. Bruder, J. W. Stewart et al., "Psychomotor slowing as a predictor of fluoxetine nonresponse in depressed outpatients," The American Journal of Psychiatry, vol. 163, no. 1, pp. 73-78, 2006.

[101] C. H. Mallinckrodt, A. Prakash, J. P. Houston, R. Swindle, M. J. Detke, and M. Fava, "Differential antidepressant symptom efficacy: placebo-controlled comparisons of duloxetine and SSRIs (fluoxetine, paroxetine, escitalopram)," Neuropsychobiology, vol. 56, no. 2-3, pp. 73-85, 2007.

[102] I. Herrera-Guzmán, E. Gudayol-Ferré, J. Lira-Mandujano et al., "Cognitive predictors of treatment response to bupropion and cognitive effects of bupropion in patients with major depressive disorder," Psychiatry Research, vol. 160, no. 1, pp. 72-82, 2008.

[103] A. B. Singh, C. A. Bousman, C. H. Ng, and K. Byron, "Psychomotor depressive symptoms may differentially respond to venlafaxine," International Clinical Psychopharmacology, vol. 28, no. 3, pp. 121-126, 2013.

[104] R. Jouvent, J. Le Houezec, C. Payan et al., "Dimensional assessment of onset of action of antidepressants: a comparative study of moclobemide vs. clomipramine in depressed patients with blunted affect and psychomotor retardation," Psychiatry Research, vol. 79, no. 3, pp. 267-275, 1998.

[105] R. T. Joffe, T. W. Uhde, R. M. Post, and M. D. Minichiello, "Motor activity in depressed patients treated with carbamazepine," Biological Psychiatry, vol. 22, no. 8, pp. 941-946, 1987.

[106] E. Álvarez, V. Pérez-Solá, J. Pérez-Blanco, J. M. Queraltó, R. Torrubia, and R. Noguera, "Predicting outcome of lithium added to antidepressants in resistant depression," Journal of Affective Disorders, vol. 42, no. 2-3, pp. 179-186, 1997.

[107] E. G. Hantouche, H. S. Akiskal, S. Lancrenon, and L. ChatenêtDuchêne, "Mood stabilizer augmentation in apparently "unipolar" MDD: predictors of response in the naturalistic French national EPIDEP study," Journal of Affective Disorders, vol. 84, no. 2-3, pp. 243-249, 2005.

[108] F. Strian, W. Albert, and C. Klicpera, "Course of depressive mood and psychomotor activation in endogenous depression," Archiv fur Psychiatrie und Nervenkrankheiten, vol. 227, no. 3, pp. 193-206, 1979.

[109] I. Hickie, B. Parsonage, and G. Parker, "Prediction of response to electroconvulsive therapy. Preliminary validation of a signbased typology of depression," The British Journal of Psychiatry, vol. 157, pp. 65-71, 1990.

[110] H. Buchan, E. Johnstone, K. McPherson, R. L. Palmer, T. J. Crow, and S. Brandon, "Who benefits from electroconvulsive therapy? Combined results of the Leicester and Northwick Park trials," The British Journal of Psychiatry, vol. 160, pp. 355-359, 1992.

[111] C. Sobin, J. Prudic, D. P. Devanand, M. S. Nobler, and H. A. Sackeim, "Who responds to electroconvulsive therapy?: a comparison of effective and ineffective forms of treatment," The British Journal of Psychiatry, vol. 169, no. 3, pp. 322-328, 1996.

[112] I. Hickie, C. Mason, G. Parker, and H. Brodaty, "Prediction of ECT response: validation of a refined sign-based (CORE) system for defining melancholia," The British Journal of Psychiatry, vol. 169, no. 1, pp. 68-74, 1996.

[113] J. Höppner, M. Schulz, G. Irmisch, R. Mau, D. Schläfke, and J. Richter, "Antidepressant efficacy of two different rTMS procedures: high frequency over left versus low frequency over right prefrontal cortex compared with sham stimulation," European Archives of Psychiatry and Clinical Neuroscience, vol. 253, no. 2, pp. 103-109, 2003.

[114] J. Höppner, C. Berger, U. Walter et al., "Influence of repetitive transcranial magnetic stimulation on special symptoms in depressed patients," Restorative Neurology and Neuroscience, vol. 28, no. 4, pp. 577-586, 2010.

[115] C. Baeken, R. De Raedt, L. Santermans et al., "HF-rTMS treatment decreases psychomotor retardation in medicationresistant melancholic depression," Progress in NeuroPsychopharmacology and Biological Psychiatry, vol. 34, no. 4, pp. 684-687, 2010.

[116] H. Ullrich, L. Kranaster, E. Sigges, J. Andrich, and A. Sartorius, "Ultra-high-frequency left prefrontal transcranial magnetic stimulation as augmentation in severely ill patients with depression: a naturalistic sham-controlled, double-blind, randomized trial," Neuropsychobiology, vol. 66, no. 3, pp. 141-148, 2012.

[117] C. K. Loo, P. Sachdev, D. Martin et al., "A double-blind, shamcontrolled trial of transcranial direct current stimulation for the treatment of depression," International Journal of Neuropsychopharmacology, vol. 13, no. 1, pp. 61-69, 2010.

[118] C. K. Loo, A. Alonzo, D. Martin, P. B. Mitchell, V. Galvez, and P. Sachdev, "Transcranial direct current stimulation for depression: 3-week, randomised, sham-controlled trial," The British Journal of Psychiatry, vol. 200, no. 1, pp. 52-59, 2012.

[119] G. Parker, D. Hadzi-Pavlovic, I. Hickie et al., "Sub-typing depression, III. Development of a clinical algorithm for melancholia and comparison with other diagnostic measures," Psychological Medicine, vol. 25, no. 4, pp. 833-840, 1995.

[120] L. L. Judd, M. H. Rapaport, M. P. Paulus, and J. L. Brown, "Subsyndromal symptomatic depression: a new mood disorder?" The Journal of Clinical Psychiatry, vol. 55, no. 4, supplement, pp. $18-28,1994$.

[121] G. S. Alexopoulos, C. Vrontou, T. Kakuma et al., "Disability in geriatric depression," The American Journal of Psychiatry, vol. 153 , no. 7, pp. 877-885, 1996. 
[122] H. Narita, T. Odawara, E. Iseki, K. Kosaka, and Y. Hirayasu, "Psychomotor retardation correlates with frontal hypoperfusion and the Modified Stroop Test in patients with major depression under 60-years-old," Psychiatry and Clinical Neurosciences, vol. 58, no. 4, pp. 389-395, 2004.

[123] A. M. Leventhal, J. W. Pettit, and P. M. Lewinsohn, "Characterizing major depression phenotypes by presence and type of psychomotor disturbance in adolescents and young adults," Depression and Anxiety, vol. 25, no. 7, pp. 575-592, 2008.

[124] M. G. Hildebrandt, K. B. Stage, and P. Kragh-Soerensen, "Gender and depression: a study of severity and symptomatology of depressive disorders (ICD-10) in general practice," Acta Psychiatrica Scandinavica, vol. 107, no. 3, pp. 197-202, 2003.

[125] D. Avery and J. Silverman, "Psychomotor retardation and agitation in depression. Relationship to age, sex, and response to treatment," Journal of Affective Disorders, vol. 7, no. 1, pp. 67-76, 1984.

[126] S. G. Kornstein, A. F. Schatzberg, M. E. Thase et al., "Gender differences in chronic major and double depression," Journal of Affective Disorders, vol. 60, no. 1, pp. 1-11, 2000.

[127] J. B. Murray, "Effects of valium and librium on human psychomotor and cognitive functions," Genetic Psychology Monographs, vol. 109, no. 2, pp. 167-197, 1984.

[128] I. Hindmarch, "Psychomotor function and psychoactive drugs," British Journal of Clinical Pharmacology, vol. 58, no. 7, pp. S720S740, 2004.

[129] D. J. King, "The effect of neuroleptics on cognitive and psychomotor function," The British Journal of Psychiatry, vol. 157, pp. 799-811, 1990.

[130] G. Parker, D. Hadzi-Pavlovic, I. Hickie et al., "Distinguishing psychotic and non-psychotic melancholia," Journal of Affective Disorders, vol. 22, no. 3, pp. 135-148, 1991.

[131] G. Hasler, W. C. Drevets, H. K. Manji, and D. S. Charney, "Discovering endophenotypes for major depression," Neuropsychopharmacology, vol. 29, no. 10, pp. 1765-1781, 2004.

[132] F. Benazzi, "Psychomotor changes in melancholic and atypical depression: unipolar and bipolar-II subtypes," Psychiatry Research, vol. 112, no. 3, pp. 211-220, 2002.

[133] E. G. Hantouche and H. S. Akiskal, "Bipolar II vs. unipolar depression: psychopathologic differentiation by dimensional measures," Journal of Affective Disorders, vol. 84, no. 2-3, pp. 127-132, 2005.

[134] P. Mitchell, G. Parker, K. Jamieson et al., "Are there any differences between bipolar and unipolar melancholia?" Journal of Affective Disorders, vol. 25, no. 2, pp. 97-105, 1992.

[135] A. C. Volkers, J. H. Tulen, W. W. Van Den Broek, J. A. Bruijn, J. Passchier, and L. Pepplinkhuizen, "24-Hour motor activity after treatment with imipramine or fluvoxamine in major depressive disorder," European Neuropsychopharmacology, vol. 12, no. 4, pp. 273-278, 2002.

[136] V. Krishnan and E. J. Nestler, "Linking molecules to mood: new insight into the biology of depression," The American Journal of Psychiatry, vol. 167, no. 11, pp. 1305-1320, 2010.

[137] E. A. Murray, S. P. Wise, and W. C. Drevets, "Localization of dysfunction in major depressive disorder: prefrontal cortex and amygdala," Biological Psychiatry, vol. 69, no. 12, pp. e43-e54, 2011.

[138] M. B. Hamner and B. I. Diamond, "Plasma dopamine and norepinephrine correlations with psychomotor retardation, anxiety, and depression in non-psychotic depressed patients: a pilot study," Psychiatry Research, vol. 64, no. 3, pp. 209-211, 1996.
[139] J. J. Dunkin, A. F. Leuchter, I. A. Cook, J. E. Kasl-Godley, M. Abrams, and S. Rosenberg-Thompson, "Executive dysfunction predicts nonresponse to fluoxetine in major depression," Journal of Affective Disorders, vol. 60, no. 1, pp. 13-23, 2000.

[140] R. J. Porter, C. Bourke, and P. Gallagher, "Neuropsychological impairment in major depression: its nature, origin and clinical significance," The Australian and New Zealand Journal of Psychiatry, vol. 41, no. 2, pp. 115-128, 2007.

[141] G. I. Papakostas, "Major depressive disorder: psychosocial impairment and key considerations in functional improvement," The American Journal of Managed Care, vol. 15, no. 11, supplement, pp. S316-S321, 2009. 


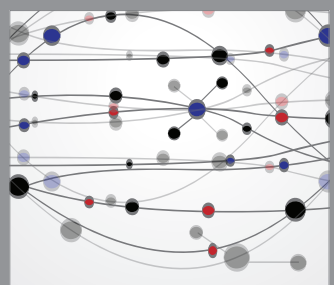

The Scientific World Journal
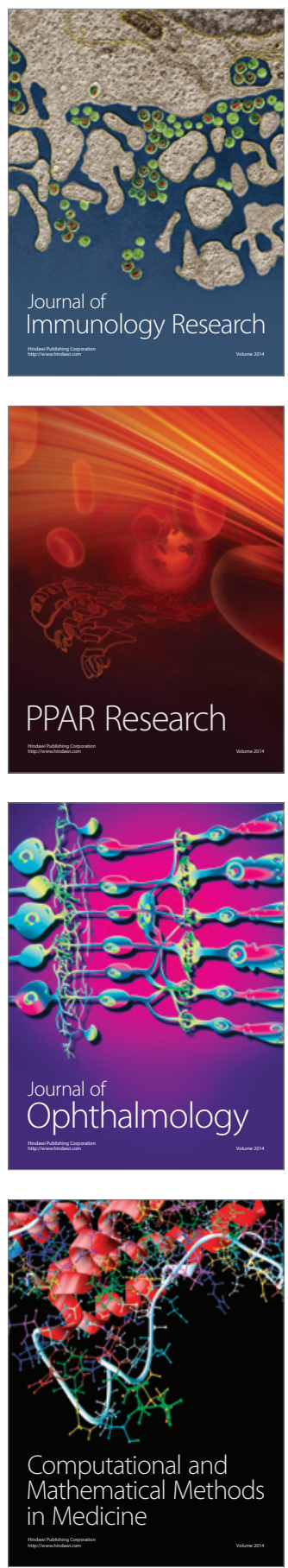

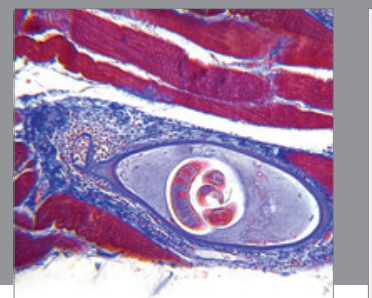

Gastroenterology

Research and Practice
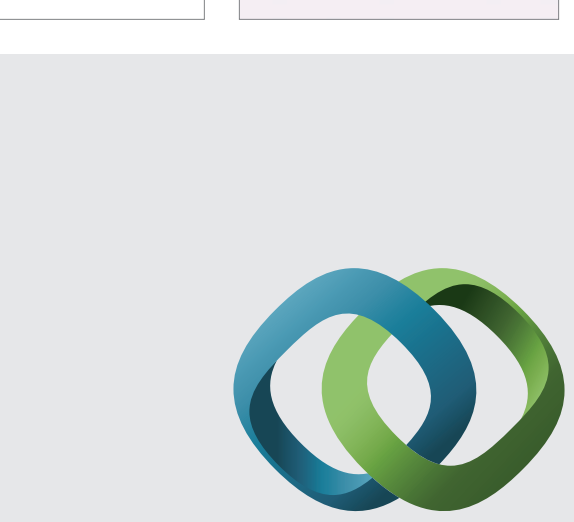

\section{Hindawi}

Submit your manuscripts at

http://www.hindawi.com
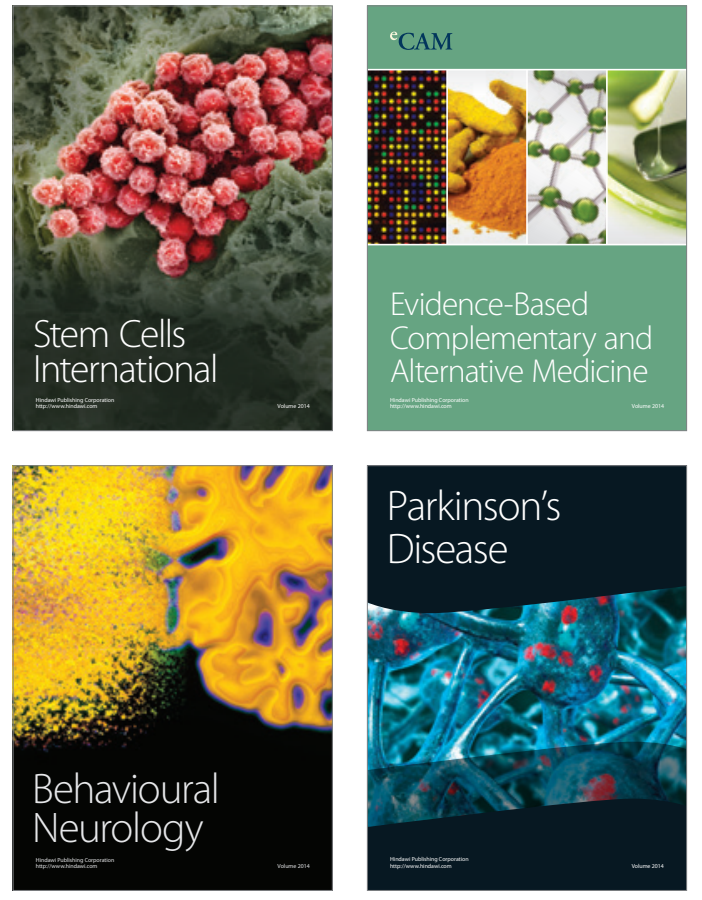
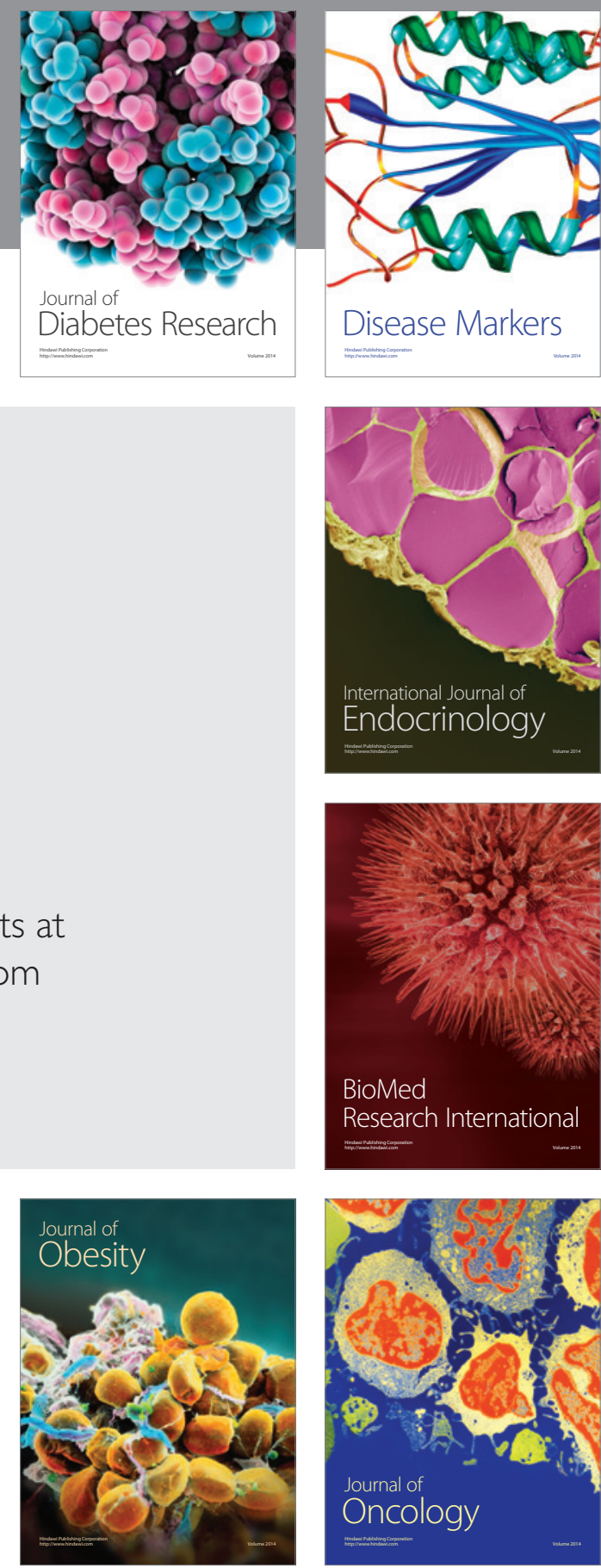

Disease Markers
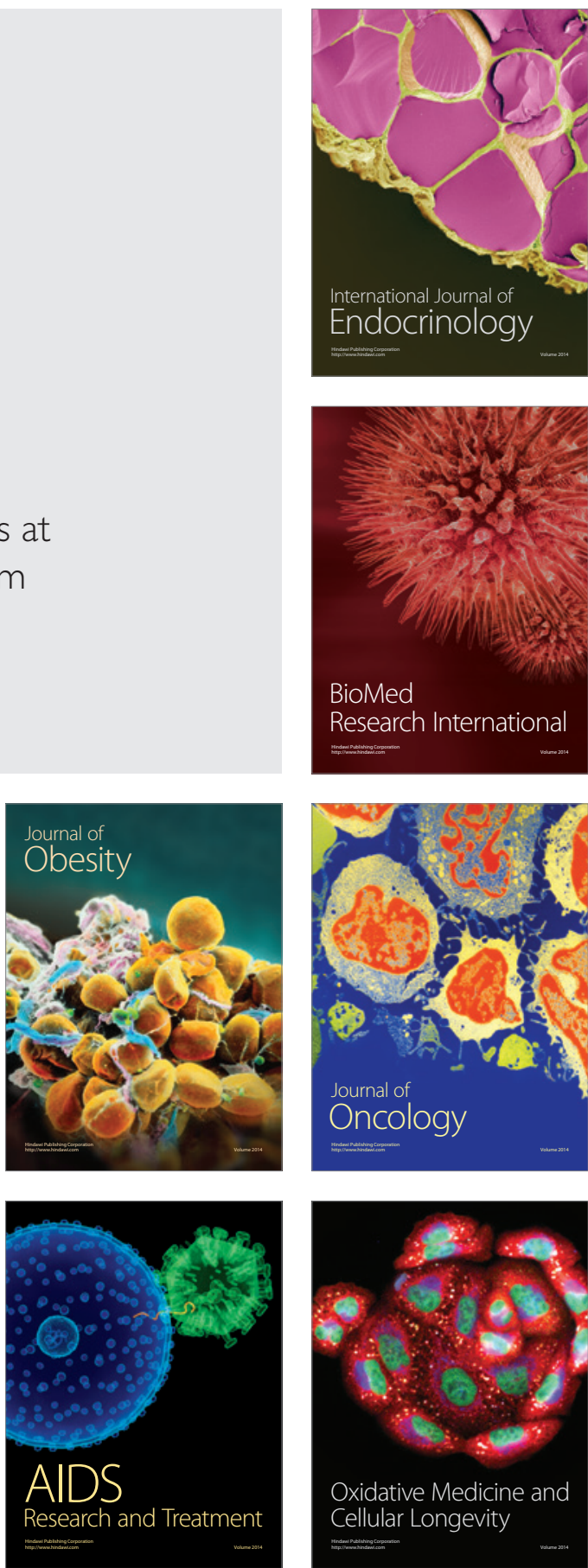